Portland State University

PDXScholar

Winter 2015

\title{
Revisiting Rajneeshpuram: Oregon's Largest Utopian Community as Western History
}

Carl Abbott

Portland State University, d3ca@pdx.edu

Follow this and additional works at: https://pdxscholar.library.pdx.edu/usp_fac

Part of the Urban Studies and Planning Commons

Let us know how access to this document benefits you.

\section{Citation Details}

Carl Abbott. "Revisiting Rajneeshpuram: Oregon's Largest Utopian Community as Western History”. Oregon Historical Quarterly 116.4 (2015): 414-447.

This Article is brought to you for free and open access. It has been accepted for inclusion in Urban Studies and Planning Faculty Publications and Presentations by an authorized administrator of PDXScholar. Please contact us if we can make this document more accessible: pdxscholar@pdx.edu. 


\section{CARL ABBOTT}

\section{Revisiting}

\section{Rajneeshpuram}

\section{Oregon's Largest Utopian Community as Western History}

IN OCTOBER 1985, a four-year effort to construct an intentional community in north central Oregon collapsed in a flurry of criminal charges and arrests of its leaders, including Bhagwan Shree Rajneesh. At its peak, Rajneeshpuram housed or hosted 15,000 followers of the Bhagwan, and its influence extended to the nearby town of Antelope, which Rajneeshees took over and renamed Rajneesh. It was, in effect, a walled community, separated from the rest of Oregon by armed patrols, legal manipulation, and deep cultural differences. The community attracted successful middleclass adherents from around the world but eventually imploded because of overreach that included acts of bioterrorism and conspiracy to murder by a small leadership clique.

How should we characterize this curious place? Was it an environmentally sensitive intentional community or a thinly disguised yuppie playground? Was it the manifestation of a powerful spiritual movement or a dangerous and aggressive cult? Was it a tragic example of betrayed hopes or a hypocritical effort to exploit the good will of the surrounding community?

Right: This photograph appeared in the Oregon Journal on July 5, 1982, showing a sannyasin meditating in Buddha Hall during a five-day festival held at Rajneeshpuram. Followers from around the world moved to the former Muddy Ranch near Antelope, Oregon, in the early 1980 s to participate in an intentional community led by Bhagwan Shree Rajneesh. 


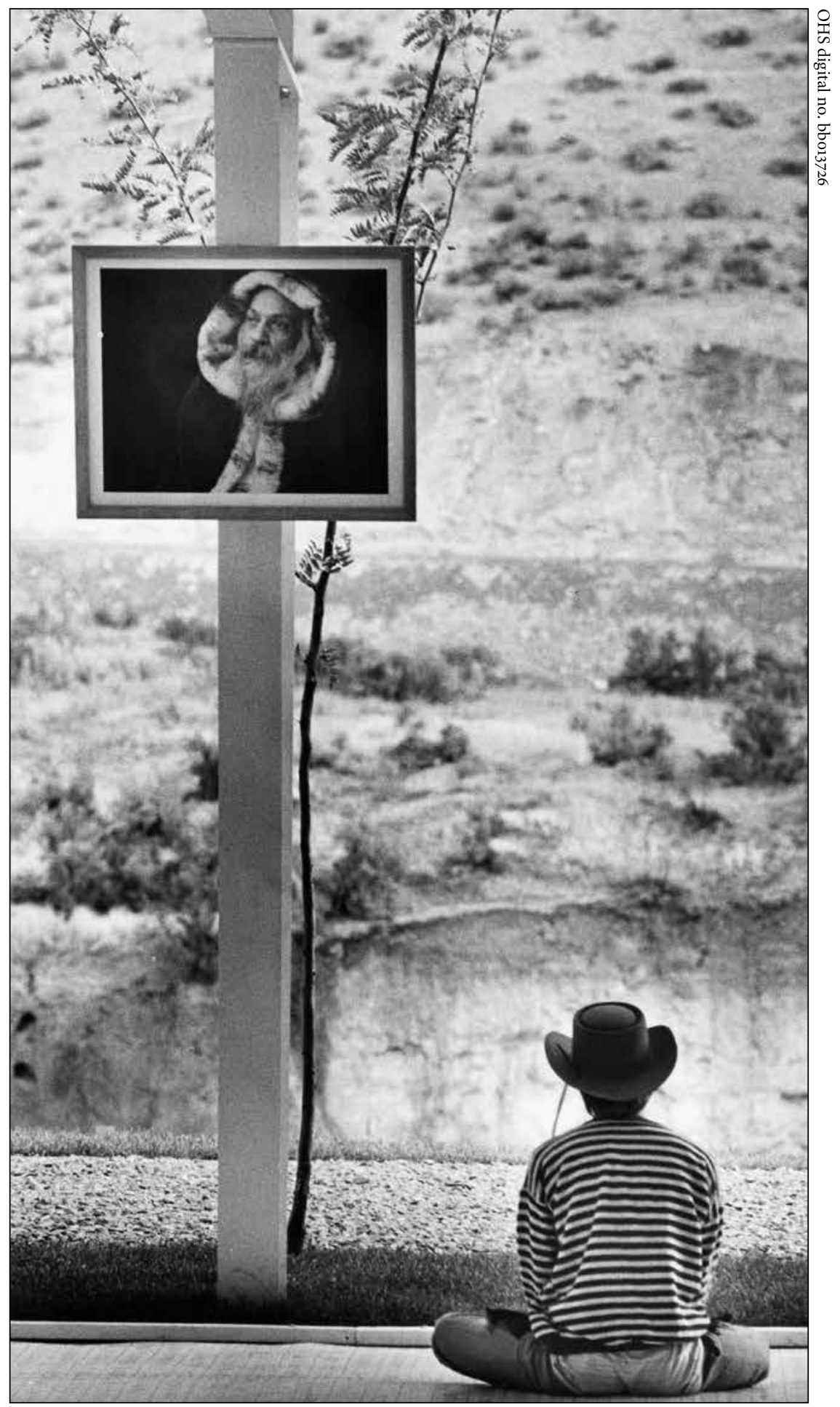




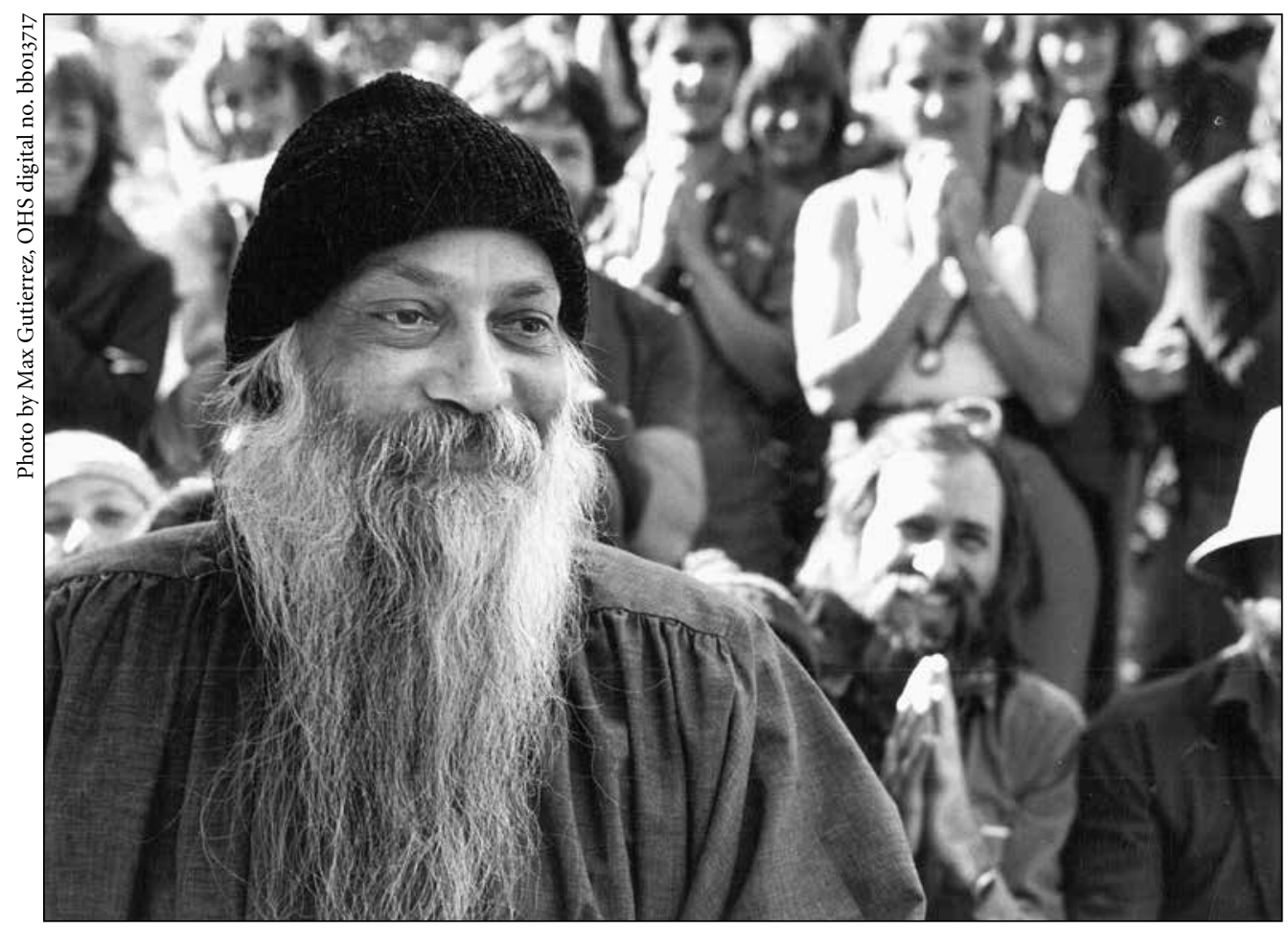

Bhagwan Shree Rajneesh stands in front of a crowd of followers during a festival. After gaining his following in India with long lectures, he chose public silence for much of his time in Oregon.

Regardless which loaded description you apply, the Rajneesh movement and its community of Rajneeshpuram make one of the most dramatic episodes in the recent history of the Pacific Northwest. After briefly summarizing this curious episode and exploring several explanations that have been offered both for its attraction to highly educated Europeans and Americans and for its failure to succeed, I want to place Rajneeshpuram within the frameworks through which we understand and interpret the history of the American West. Rajneeshpuram was a western community from start to finish, and its history is a western story just as much as it is a story about spiritual quests and new religious movements.

Western history centers on the processes of migration, settlement, displacement, and rearrangement that have integrated the resources and peoples of western North America into a global economy and produced the 
multiethnic social landscape of the twenty-first century. Within this sweeping generalization are the stories of specific places and specific groups - Oregon Trail pioneers and sodbusters, railroad builders and Wobblies, Chinese merchants and Cheyenne buffalo hunters, Japanese orchardists and Mexican citrus workers. In very rough division, narratives of conquest and migration dominate the eighteenth and nineteenth centuries. The focus shifts in the twentieth century to the challenges of consolidation and maturity as settlers moved in, resource booms faded or stabilized, and city people outcompeted and outvoted country people. Think of the nineteenth century as the West's adolescence and the twentieth as its growing-up century.

Rajneeshpuram and its residents - as short-lived as the community was - recapitulated several of the important facets of western development. In some cases, Rajneeshees explicitly claimed the historical parallels, such as the earlier belief in irrigated agriculture as a progressive and beneficent form of settlement. In other cases, we can identify patterns that they did not articulate, including similarities to Mormon Utah. Ultimately, the Rajneeshees of Oregon were not able to control their own narrative. They claimed an affinity to specific positive stories about the western American experience, but they found themselves constrained and enmeshed in a far thicker history than they wished to acknowledge.

\section{THE RISE AND FALL OF A UTOPIA}

Bhagwan Shree Rajneesh was a spiritual teacher who developed a substantial international following in Pune, India, during the 1970s. Seekers came from Europe and America to listen to his teachings for periods ranging from days to years as they sought the designation of sannyasin, traditionally a person who has renounced material desires in favor of a simple spiritual life. Rajneeshee, the popular term for sannyasin, gained Bhagwan's sanction in 1982. In long monologues that drew eclectically on Zen Buddhism, Hindu traditions, progressive psychology, Gurdjieff, and Nietzsche, the Bhagwan proclaimed a doctrine of self-fulfillment without and beyond constricting rules and narrow morality. Enlightened capitalism and the pleasures of the world were to be embraced and combined with open-ended spiritualism, crafting an ideal that he called Zorba the Buddha. ${ }^{1}$

The Bhagwan's combative nature offended Hindu neighbors and caused him to pick fights with Indian officials and to insult Indian politicians, who responded by blocking expansion plans for his ashram, denying visas to westerners, and opening criminal investigations. Under legal and financial pressure, he decided in 1981 to relocate to the United States, abandoning his ashram to creditors and thousands of followers to their own devices. 


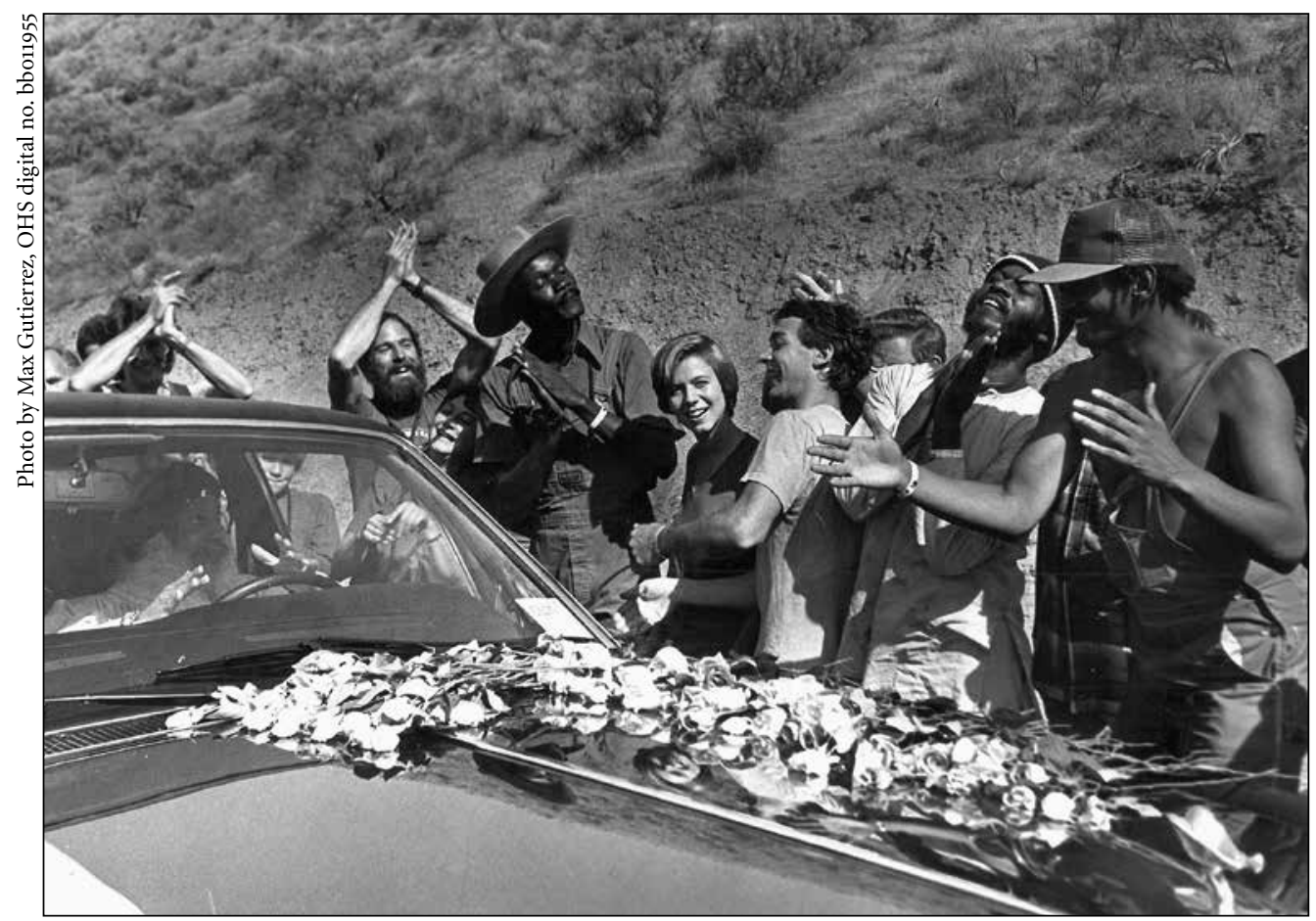

In this undated photograph, the Bhagwan passes a group of sannyasins during one of his daily afternoon drives. As with many Rajneeshee activities, the drives had very different meanings to insiders and outsiders. To community members they were a form of affirmation and celebration, while to many other Oregonians they symbolized nonspiritual self-indulgence.

On June 1, 1981, he suddenly and secretly left Pune for the United States, stopping in a recently purchased mansion in Montclair, New Jersey. He and his chief lieutenant, Ma Anand Sheela, quickly turned their eyes westward. ${ }^{2}$ On June 13, Sheela's second husband negotiated purchase of the neglected 64,000-acre Big Muddy Ranch in southern Wasco County and northern Jefferson County, Oregon, from absentee owners, paying \$5.75 million for the site of their planned community. ${ }^{3}$

The new settlement quickly attracted followers in the hundreds and then thousands, largely North Americans but also many Europeans. The cover story - that the goal was to create a communal farm for forty people - quickly frayed as the community took out dozens of building permits, purchased property in Antelope, and continually stated changing plans to 
reporters and local residents. The intention to create a major Oregon community was obvious after the Bhagwan arrived at the beginning of September. Over the next three years, what was initially called Rancho Rajneesh grew to roughly 2,500 full-time residents, a population that swelled during summer festivals to 15,000 in 1983 and 13,000 in $1984 .{ }^{4}$ The community developed the appurtenances of a regular town, including water and sewer systems, hospital, shopping mall, and police force. In addition to properties in Antelope, Rajneeshees also bought a former women's residence hotel in downtown Portland to accommodate visitors to and from the community, roughly a three-and-a-half hour drive from Portland. Sociologist Marion Goldman has succinctly summarized the idealistic goal of many of the new residents: "They hoped to blend spirituality with materialism while building an intentional community that could also serve as a destination resort and luxurious pilgrimage center for sannyasins from all over the world."5

Oregonians greeted the development with much bemusement, some support, and rapidly growing distaste. The latter sentiment was exacerbated

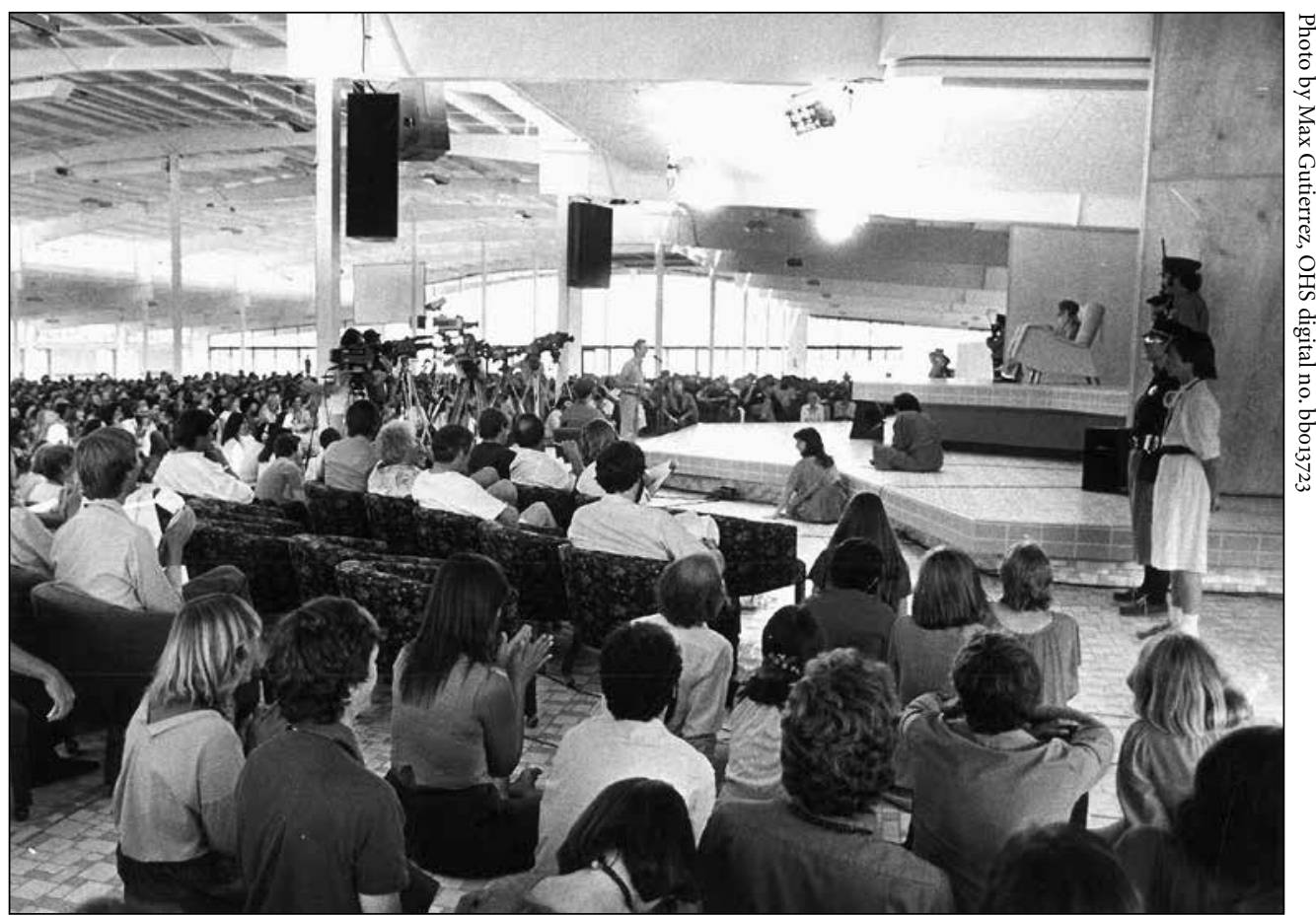

The Bhagwan, sitting on a dais on the far right in this photograph, leads a session during a summer festival at the Meditation Center at Rajneeshpuram. 
by the in-your-face attitude of many adherents, their increasingly intense efforts to control access to the community, their increasingly prominent displays of weaponry, and the Bhagwan's apparent self-indulgence in the form of dozens of Rolls Royce automobiles in which he was regularly driven the forty-five miles to the town of Madras. It appeared to outsiders to be an uncomfortable mixture of serious religious community, manipulative cult, and big summer camp for adults (to borrow Frances FitzGerald's metaphor). ${ }^{6}$

If it was to grow, the new community needed municipal status. As long as it was unincorporated rural land, it was subject to Wasco County and Jefferson County zoning for exclusive farm use, making large-scale, permanent development impermissible. In response, the newcomers organized as the City of Rajneeshpuram; Wasco County approved the incorporation in the spring of 1982. As a municipality, the community now controlled land-use decisions and was no longer constrained as rural land, so long as it adopted a comprehensive plan that met Oregon's state planning goals. ${ }^{7}$ Rajneeshees also used their numbers to assume political control of the tiny town of Antelope, the starting point for the only road to the community, thereby controlling a second municipality where they could locate nonrural facilities.

Rajneeshpuram posed a dilemma for liberal Oregonians. Some emphasized the importance of defending the free practice of religion. Many environmentalists and land-use advocates, however, considered Rajneeshpuram an end-run around Oregon's comprehensive land-use planning system and challenged the legality of the incorporation, embroiling the Rajneeshees in the specialized realm of Oregon land-use law. In a complementary action, Oregon Attorney General David Frohnmayer argued vigorously that the incorporation violated the constitutional separation of church and state because the community was closed to non-adherents and all land was owned by a religious entity.

On September 14, 1985, Ma Anand Sheela and several other leaders abruptly left Rajneeshpuram as evidence mounted that they had conspired in a series of crimes. These included arson, wiretapping within the community, conspiracy to commit murder, and the planting of salmonella bacteria in the salad bars of several restaurants in The Dalles, the county seat for Wasco County, sickening 750 people. Bhagwan Shree Rajneesh denounced Sheela, then left the community by chartered plane in October, perhaps in search of a vacation or perhaps attempting to flee from prosecution. He eventually reached a federal plea bargain on immigration fraud charges and agreed to leave the United States. Ma Anand Sheela 


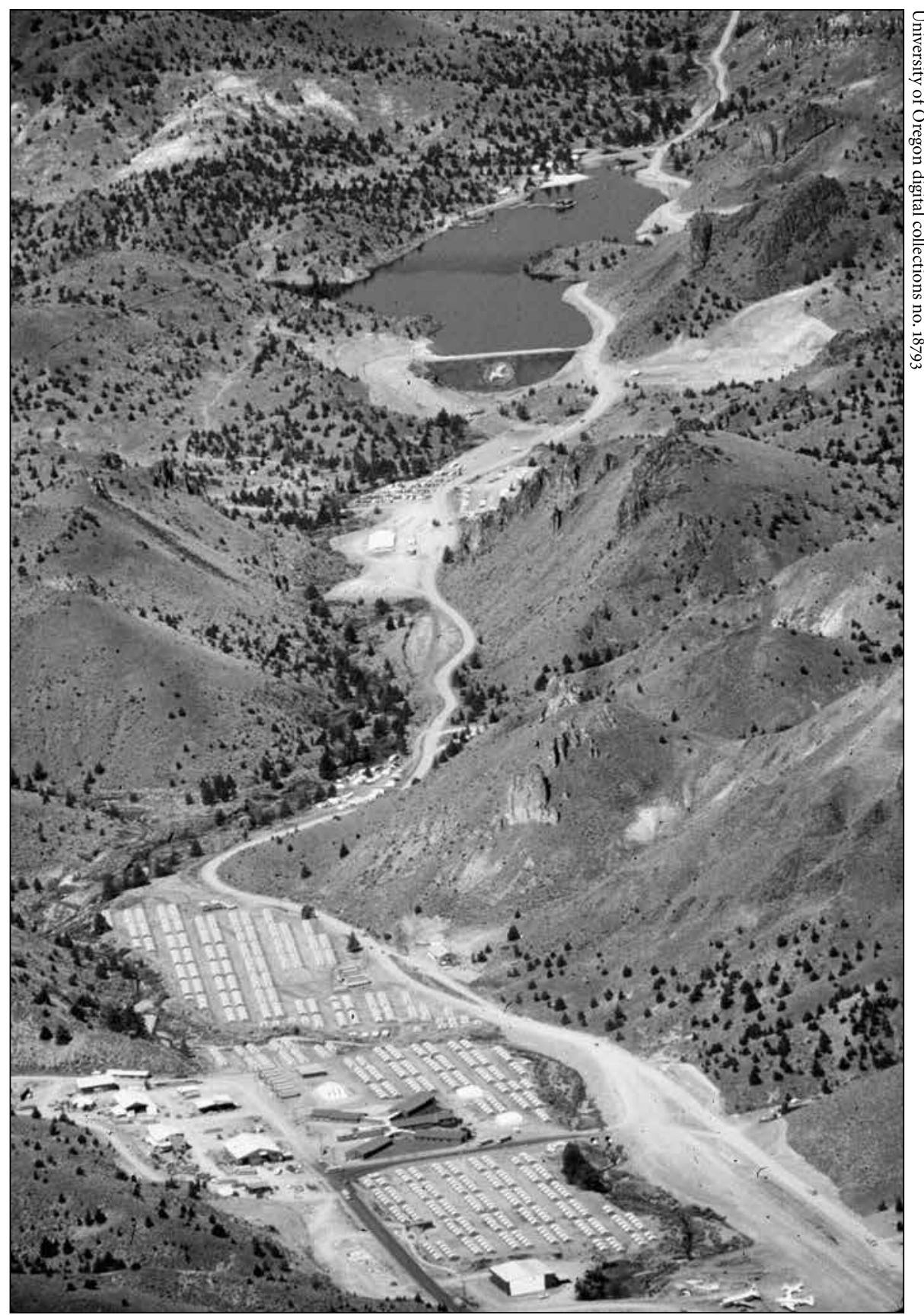

Rajneeshpuram, shown here in July 1983, was incorporated by Wasco County in 1982. At the top of this photograph is human-made lake Patanjali, and the town center is near the bottom. 
and several other leaders were convicted of an assortment of crimes. Remaining Rajneesh leaders announced the final closure of the decimated community on November 22. By 1986, Rajneeshpuram was another of the many western ghost towns. A church youth camp now makes use of many buildings and facilities.

The dramatic Rajneesh saga in Oregon left a mix of recycled and abandoned buildings and thousands of lives changed for better or worse. It also generated a flood of commentary and analysis, starting in the mid $1980 \mathrm{~s}$ with quick-off-the-press memoirs and journalism, both sympathetic and hostile. The first comprehensive account, by a sympathetic Oregon journalist, depicted successful community-making in the face of unreasoning hostility. A similar volume, published in 1986, revolved around the conflict of creative spirituality and religious bigotry. ${ }^{8}$ Several subsequent memoirs by former Rajneesh followers are organized around their authors' personal journeys of belief and disillusionment. ${ }^{9}$ Journalist Win McCormack collected articles from Oregon Magazine into a deep negative exposé..$^{10}$ Most widely circulated of the early accounts was Frances FitzGerald's nuanced and finely drawn chapter in Cities on a Hill, her report on four distinctive American communities of the 1980s (Liberty Baptist Church in Lynchburg, Virginia; Sun City, Florida; the Castro district in San Francisco; and Rajneeshpuram). The chapter is organized around a shift from positive to negative evaluation on the part of an initially sympathetic observer. ${ }^{11}$

Scholars have been equally intrigued. Social scientists, several of whom did field work and conducted interviews before and after the city's demise, have wanted to understand adherents' experience with the Rajneesh and Rajneeshpuram: What did it mean to be a sannyasin who relocated to be near like-minded people and Bhagwan Shree Rajneesh himself? Why were individuals drawn to the beliefs and practices? Why did they join isolated communities? How did the experience change them? ${ }^{\text {?2 }}$ Specialists in religion have approached the story from the standpoint of belief systems: What did the Bhagwan teach? What did his followers hear and believe? How and why were a set of disparate teachings institutionalized as a religion? ${ }^{\text {?3 }}$

Sannyasins, of course, could have absorbed the same messages and experienced the same personal changes in many different locations - directly from the master in Pune as many did in earlier years, and indirectly through his writings and tapes. They could have tried to express and reinforce their beliefs through communal living in many different locations - as they did in small communities in Britain and elsewhere in the United States before and after Rajneeshpuram. Nevertheless, thousands chose to do so in a very specific part of the American West. In the process, they reenacted narratives of western American history. 


\section{BACKWOODS UTOPIAS}

The first narrative is the most broad: Successive American Wests - regions of sparse but growing Euro-American settlement — invited the experimental and idealistic communities that historian Arthur Bestor called "backwoods utopias." ${ }^{14}$ Accessible but still developing regions offered cheap and abundant land and limited interference from neighbors, inviting idealists to construct new model societies in places with few pre-existing social, economic, or legal constraints. Philip Porter and Fred Lukerman found that a majority of utopian communities in the nineteenth century were located within a hundred miles of the standard frontier line of six persons per square mile. The proliferation of utopian experiments on the Pacific coast from the mid nineteenth into the twentieth centuries has been well documented by Robert Hine, Charles LeWarne, and James Kopp. ${ }^{15}$ More recently, the thinly settled Pacific Northwest backcountry has attracted a sizable share of countercultural communes and survivalist enclaves. ${ }^{16}$

The Rajneesh deliberately chose to locate in the empty West. There may be places in Oregon that are further from metropolitan centers - towns such as Wagontire, Lonerock, and the aptly named Remote — but the Big Muddy Ranch was hard enough to reach. It was a 50-mile drive from Madras, the seat of government for Jefferson County, and 100 miles from The Dalles and the Wasco County courthouse. It was 120 miles from Portland by crow and 175 miles by car. A circle with a 50-mile radius drawn around Rajneeshpuram embraced only one town with more than 1,00o people and one other of more than 500. It is likely that Ma Anand Sheela and Bhagwan expected the physical isolation to translate into freedom of action.

Within this framework of experimental communities in the so-called wilderness, two other specific frontier utopias are especially relevant. New England towns of the seventeenth century have been described by Kenneth Lockridge as Christian, utopian, closed, corporate communities. To be a member of the town was to be part of a closed or exclusive club that exercised authority as a group and whose core entrance requirement was Puritan church membership. When a group of settlers planted a new town, the community as a whole controlled the land and its allocation to individual families, and the community as a whole made key decisions about the right ordering of local affairs. ${ }^{17}$

The Rajneesh leadership was quick to claim the analogy of such early New England towns and their deep resonance with the national founding mythology. Rajneeshpuram was certainly utopian, closed, and corporate. The church, through a nonprofit corporation, owned all the land. Only adherents of Rajneeshism could gain permanent residence. On a personal note, I attended a conference on affordable housing in Portland early in the 


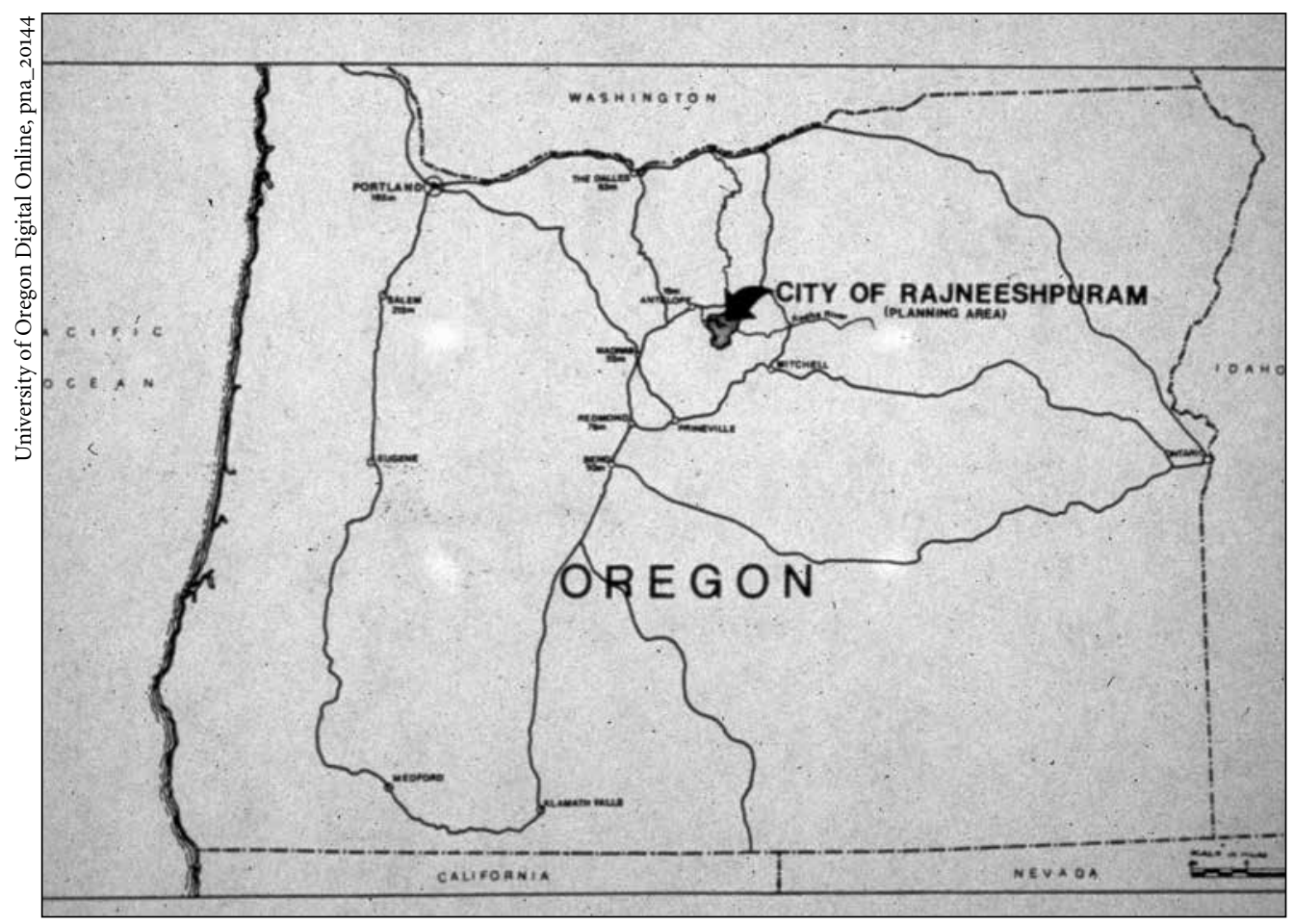

Rajneeshpuram was located in Wasco County in central Oregon, near the city of Antelope. This map from an undated state report shows the City of Rajneeshpuram planning area.

community's development and fell into conversation with a very articulate Rajneesh representative. His answer to my fumbling suggestion that the community might not merit formal incorporation as a municipality because of its religious exclusiveness was to bring up the Massachusetts example: If we admired the gritty folks of early Dedham and Sudbury, then we should surely admire the gritty new community in central Oregon and understand is members' goals through the lens of religious toleration. Even if we remembered that Massachusetts authorities had been unkind to Quakers and Baptists, we still were asked to admit that the historical parallel was telling and that the brightly clothed settlers (Rajneeshees favored tones of red, pink, purple, and orange as "sunrise colors") were the modern heirs of the soberly clad Puritans who were essential to the nation's foundation story.

With its high desert location, Rajneeshpuram also fits a related narrative much more dear to western historians — that of Deseret. Like the Mormons 
(officially the Church of Jesus Christ of Latter-Day Saints and also known simply as LDS), the Rajneesh considered themselves a religious community in flight - if not from murderous persecution, at least from an unsympathetic and intrusive Indian government getting testy about taxes. The Pune ashram had peaked in the late 1970 and faced burdensome debts. A network of centers in other locations struggled to attract participants and cover costs. ${ }^{18} \mathrm{~A}$ new start in the American West might attract new adherents and place the movement on a stronger financial footing. The consequences of failure were vastly higher for

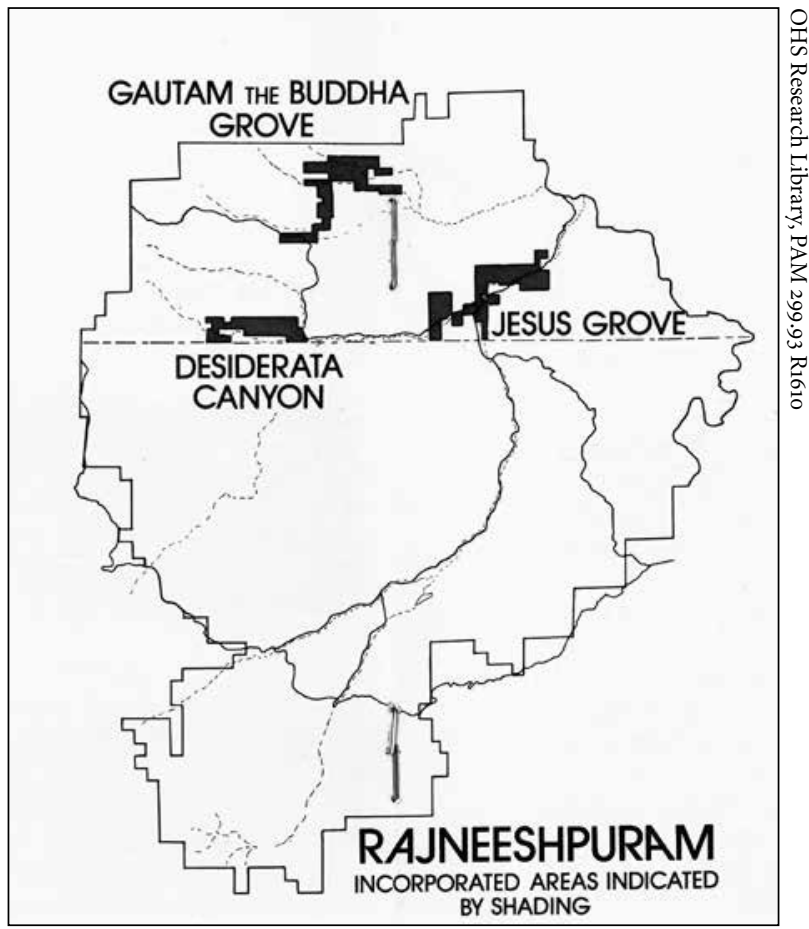

This map detailing the incorporated areas of the City of Rajneeshpuram was published in the Rajneesh Foundation International's pamphlet titled Rajneeshpuram an Oasis in about 1982. the LDS pioneers than for Rajneeshees, but the motivations were similar.

Both Mormons and Rajneeshees emerged in eras of religious ferment and spiritual innovation - the former in the spiritually tumultuous Burned-Over District of western New York State during the Second Great Awakening, the latter out of the cultural and countercultural upheavals of the 1960 and 1970s. Competing in what was effectively a free market in religion and spiritual practice, each offered a welcoming belief system that was attractive to individuals disillusioned by other formal religions. Mormon doctrine was open enough to be comfortable for Christians of many backgrounds while drawing a clear line against the world. Its version of perfectibility resonated with powerful contemporary trends in Methodism and the Holiness Movement, providing sanctuary and reassurance while drawing a clear line against the world. As Mormon sociologist Lowry Nelson put it: "Those weary of the pulpit thunderings of hell-fire could contemplate the more comforting Mormon doctrine of salvation for all 
and eternal progress for those who would order their lives in accordance with revealed instructions." ${ }^{\prime 19}$ The Rajneesh movement was explicitly eclectic. The Bhagwan's lectures drew on a famously scattered range of sources from Asian religion and European philosophy, and there was no creedal test for taking sannyas. Christians, Jews, atheists, humanists, and anyone else might come to the movement to pursue the secular salvation of self-actualization and individual fulfillment.

Overlapping the welcoming belief systems was openness to important places for women in both movements. Women outnumbered men at Rajneeshpuram by 54 to 46 percent, and they filled many of the leadership and professional roles. Observers noted that Rajneeshee women were often more assertive than men, and participation was liberating and affirming for many. ${ }^{20} \mathrm{~A}$ century earlier, facing the need to mobilize all available resources in the first decades of Utah settlement, Mormons also opened education to women, valued the professional skills of women as teachers and medical workers, and extended the vote to women in 1870 . Lawrence Foster has argued that polygamy itself encouraged greater female autonomy: "In the absence of their husbands, who could often be gone for extended periods of time, plural wives ran farms and businesses and became of necessity the acting heads of households." ${ }^{21}$ Foster's argument is accepted as accurate to a point, but it is important to note that women exercised their autonomy within limits set by the patriarchal framework of the church. The Bhagwan was a patriarchal figure but did not exercise authority in the same way as the Mormon leadership, and the women in his inner circle therefore had much more freedom of action.

The Rajneesh venture into Oregon even started, reportedly, with a Brigham Young moment. In the founding myth for Rajneeshpuram, Sheela, scouting potential land purchases in mid 1981, settled on the Big Muddy Ranch at first sight: "This is it," she announced, echoing Young's famous phrase, "This is the place, for the Lord has shown it to me in a vision," spoken as he caught his first glimpse of the Salt Lake Valley. ${ }^{22}$ Neither story is likely true, however. Lewis Carter makes it clear that the Big Muddy quote is a constructed story, since Sheela's husband negotiated the purchase directly with the North Plains Land and Investment Company of Dumas, Texas, but it fits the Rajneesh sense of mission. ${ }^{23}$ The Brigham Young quote was supposedly recorded by Wilford Woodruff twenty-two years after the event, but no contemporary account documents Young's words — not that many in his party were not thrilled by the sight. ${ }^{24}$

Unlike many frontier utopias whose members looked inward, but much like the LDS colonists, the Rajneeshees looked vigorously and sometimes aggressively outward. Brigham Young aimed to construct a self-governing 


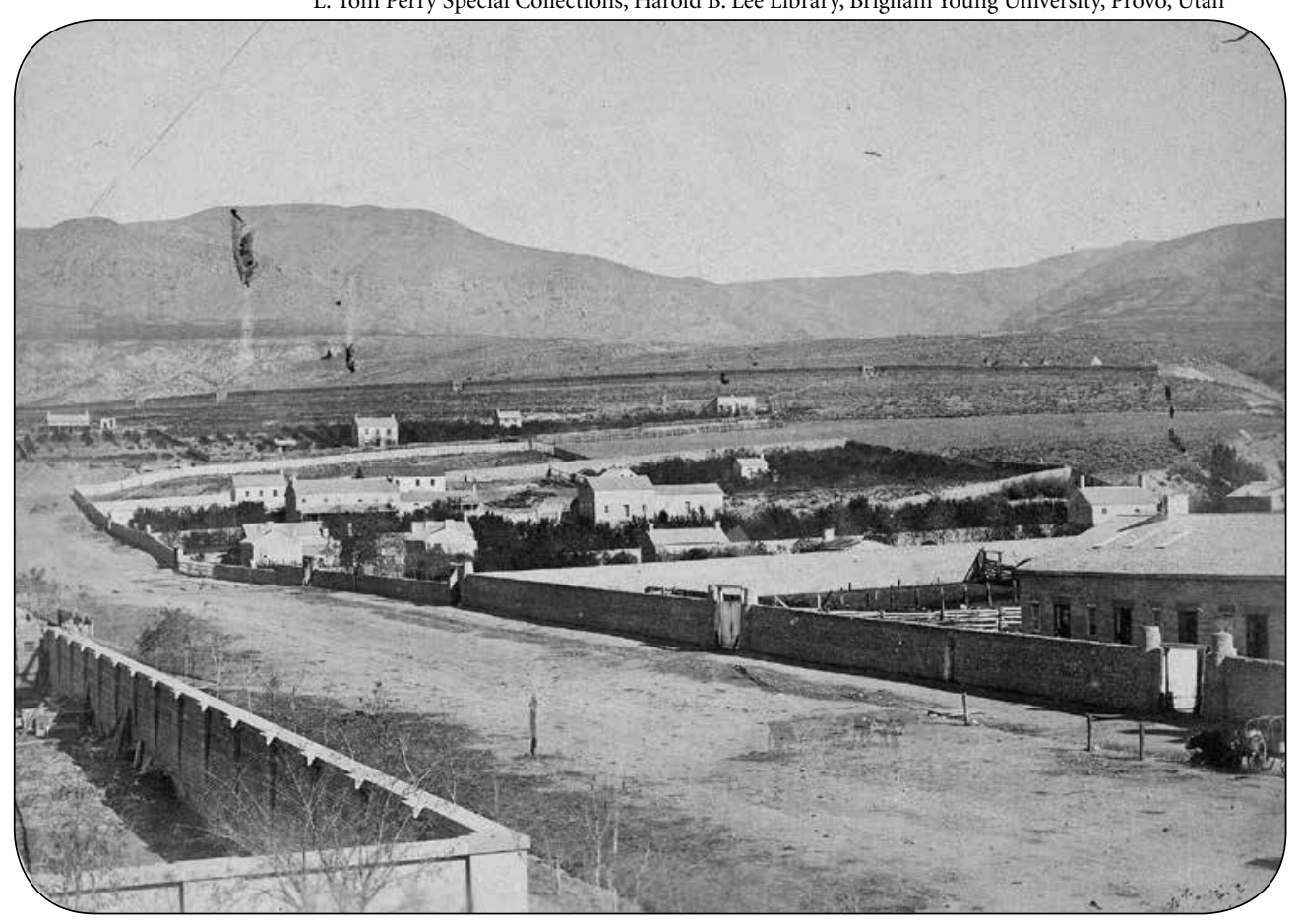

As the center of Mormon settlement in the intermountain West, Salt Lake City was a tacit model for Rajneeshpuram. This view of southwest Salt Lake City was photographed in the 1850 or 1860 s.

commonwealth, proposing a state of Deseret in 1849 to cover most of the vast interior basins and reaching to the sea in southern California (encompassing all or part of eight modern states). As geographer Donald Meinig puts it, "Brigham Young not only envisioned a New Jerusalem, but placed it within a vast American Israel. He marked out that area on the map, gave it a name ... and hurried to establish a hold on it." ${ }^{25}$

The new Mormon settlements can be grouped as inner colonies and outer colonies. Because Salt Lake City and environs could not absorb all the anticipated immigrants, the church began to extend settlement north and south, to Ogden and Provo, and then further to places such as Nephi and Fillmore. In the same decade, from 1848 to 1858, Young also directed the establishment of outer colonies both to claim territory and to hold open migration routes. He took over Fort Bridger as a base for the "church trains" sent to bring emigrants across the plains and dispatched settlers to the far corners of Deseret to create anchors and entry points for converts 


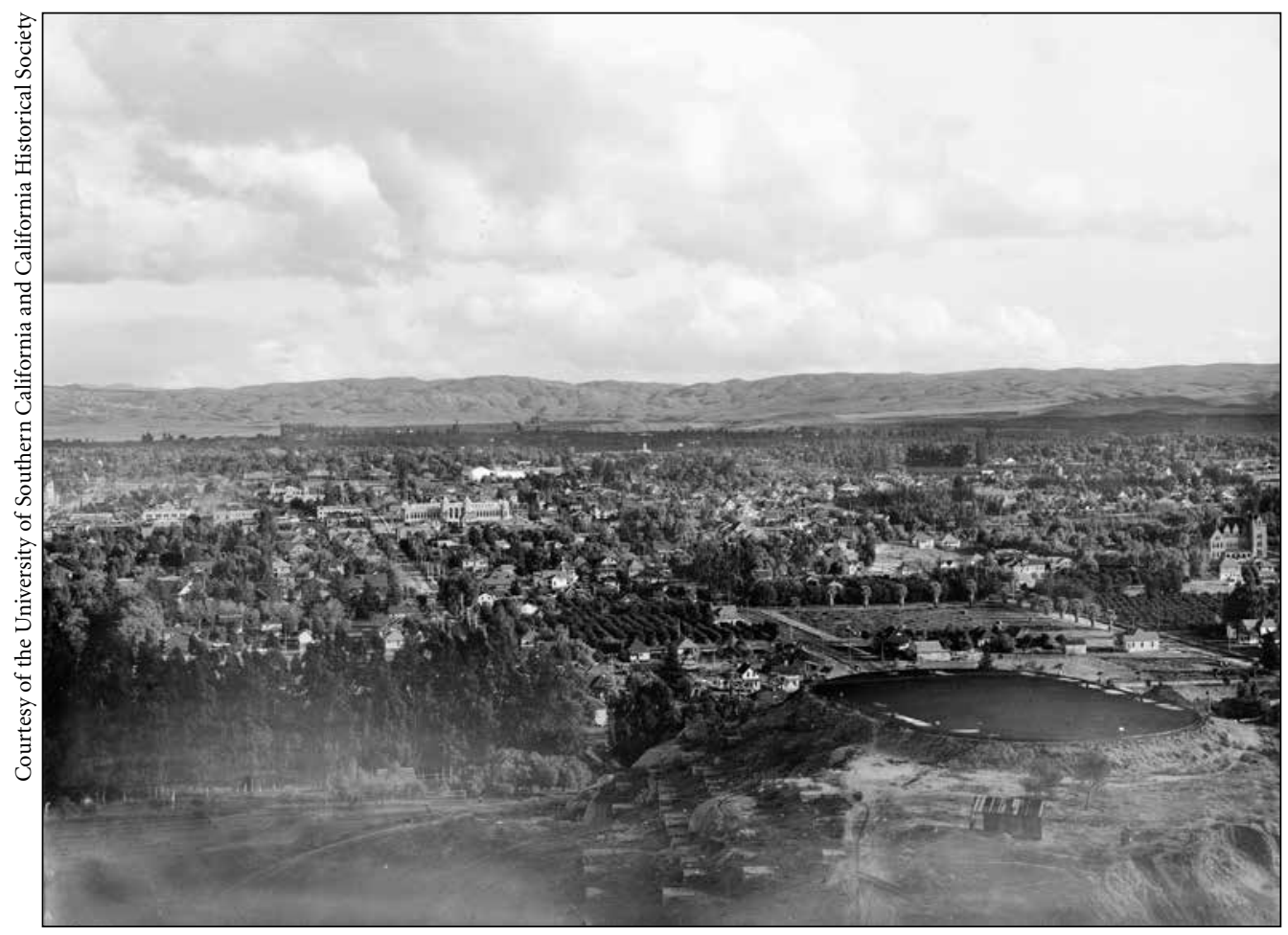

Early western irrigation projects led to the development of garden cities, or moderately sized regional centers around irrigation districts, such as Riverside, California, shown here in this panoramic view in about 1910.

from Europe and the eastern United States, particularly at Mormon Station, near Carson City (1850), and at San Bernardino (1851) and Las Vegas Springs (1855), which were to secure an expected immigration corridor from San Pedro, California. ${ }^{26}$

Although neither the Rajneeshees' numbers nor their ambitions reached the grand scale of Deseret/Utah, some parallels are instructive. The Rajneesh hotel in downtown Portland, twenty minutes from the airport, facilitated interaction with the world and was a way station for immigrants, thus serving as an "outer colony" in a role similar to that hoped for San Bernardino and realized by Mormon Station. The political coup that gave Rajneeshees control of Antelope effectively doubled their territorial sphere of influence. The re-governed town contracted with Rajneeshpuram for police services, turning the small municipality into a check point on the single, fourteen-mile road into the larger new city. Continuing the analogy with Utah/Deseret, the 
small town served both as an "inner colony," housing services and activities necessary for the larger community, such as schools and waste disposal, and also an "outer colony," acting as part of the city's defensive perimeter. A failed scheme to take over Wasco and Jefferson county governments in 1984 would have been the next step toward carving out a central Oregon theocracy. From 1983 into 1985, visitors to Rajneeshpuram had to pass multiple check points, and the city's Peace Force became increasingly numerous and well-armed. With up to 150 members, or 5 percent of the permanent population, it was most visible as a border patrol. ${ }^{27}$

The Mormon experience suggests another western history framework that centers on the development of an agricultural economy. Mormon Utah depended on irrigated farming. Church officials sent exploring expeditions from Salt Lake City to scout good town-sites on westward facing slopes of Utah's valleys, eventually planting sets of towns that array north-south at ten- to twenty-mile intervals along the western base of Utah's mountain ranges. The leadership picked settlers with a mix of skills and sent them forth to create new towns such as Fillmore and St. George. Settlers customarily received town lots large enough for gardening as well as farm lots beyond. As the townspeople built the necessary waterworks, church officials managed and distributed the water as a common resource. ${ }^{28}$

The Utah communities were early examples of the century-long story of western irrigation projects undertaken at increasing scales, the expansion of irrigated agriculture, and the growth of what one might call "garden cities" - moderately sized regional centers that grew initially as distribution and support centers for irrigated districts: Grand Junction, Boise, Klamath Falls, Fort Collins, Phoenix, Riverside, Fresno, and, of course, Garden City, Kansas. Town makers often sited these places at the meeting points of mountain and plain, where steep slopes and gorges spread into widening valleys that slowed streams and invited engineering with upstream dams, head gates, and canals to lead water over benchlands and into alluvial fans to nourish orchards. When the engineering worked, narrow riverbank oases could become broad gardens. This history began with the Mormons, continued with cooperative farm colonies in Colorado and California, and climaxed with federal irrigation projects from the Newlands Reclamation Act of 1902 through the New Deal. ${ }^{29}$

The builders of Rajneeshpuram were improvers in this tradition - pioneers who were making a garden from a dry landscape (with fourteen inches of precipitation annually, it is not quite a desert). Using terms like "oasis community" and "Garden of Eden," their narrative of progress emphasized that they were taking a neglected and underutilized tract and making it productive, adding several thousand acres to Oregon's two million acres 


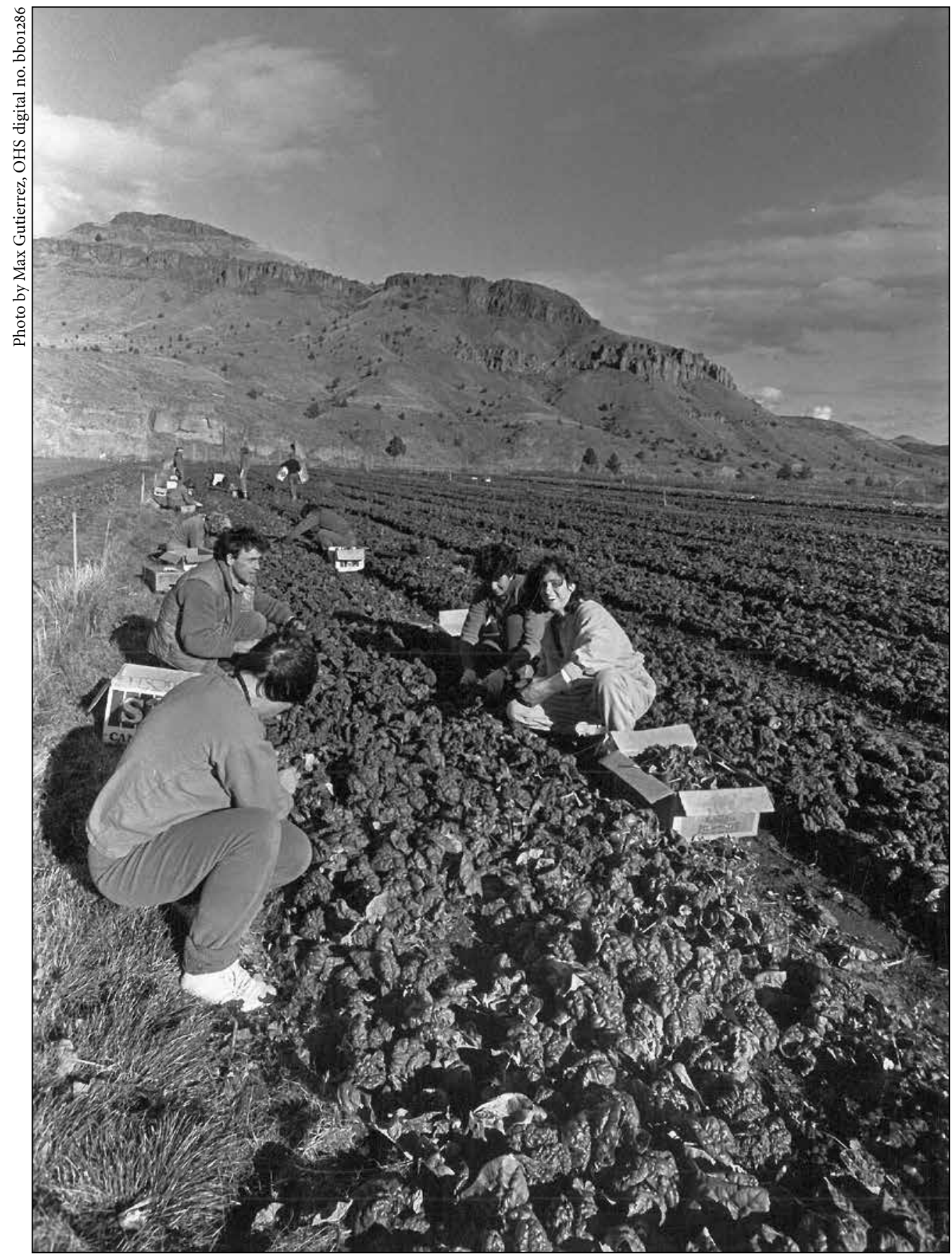

In November 1985, as the city was failing politically, sannyasins harvest spinach in the fields at Rancho Rajneesh. The ranch held 2,70o acres of irrigated fields fed by check dams and ravines built by Rajneeshees. 
of irrigated farmland. To revitalize the overgrazed and eroded landscape, they built check dams in ravines and the larger Gurdjieff Dam to impound 1,000 acre-feet of water rather than allowing it to flow into the canyon of the John Day River. They sank dozens of wells, pumped water from the John Day River, restored stream beds and margins, cultivated organic crops, built greenhouses, and installed multiple sets of irrigation pipes. The water served 2,700 acres, with crops of wheat, barley, and fodder for cattle. Eighty acres were for vegetables, grapes, and other fruits. They encouraged chickens to lay eggs by piping in classical music and tapes of the Bhagwan's monologues. The settlement was, in the Rajneeshee view, a loving and productive redemption of a damaged environment. ${ }^{30}$ At least officially as a community, Rajneeshees showed no more doubt that their impact was positive than had Horace Greeley, William Smythe, George Chaffee, and other advocates and entrepreneurs of western irrigation, and they used this facet to positively market the community in the midst of land-use controversies. ${ }^{31}$

Residents from Jewish backgrounds sometimes referenced the kibbutz experience of the 1930s, 1940s, and 1950s, when Jewish settlers in Palestine caused the desert to bloom in the midst of hostile physical and social surroundings. ${ }^{32}$ (Rajneeshism was one of the few contemporary, alternative spiritual movements that appealed to Jews, who accounted for 30 percent of Rajneeshpuram's first wave..$^{33}$ ) There are indeed some kibbutz parallels. These include settlement in compact villages, need for self-defense, shared construction and maintenance of agricultural infrastructure, and assumptions of superiority to pre-established populations - the ideas that Jewish agricultural settlers would take neglected land and show Arab farmers what could be done with modern techniques. Historian Ilan Troen also describes the kibbutz and similar moshav, terms with some applicability to Rajneeshpuram, as "homogeneous societies for cultural reasons. They were designed as communities in which an authentic, modern Jewish society would be regenerated.... In this sense they remained covenantal societies even without the religious commitments of the first pioneers." ${ }^{34}$ Not surprisingly, Rajneeshees said little if anything about the several dozen Jewish farming colonies that idealists had scattered across the United States from New Jersey to Oregon from the 188 os to the 1910 - — both because they were obscure and because they were practical failures. ${ }^{35}$

Overarching the storylines of frontier utopias and the blossoming desert is the narrative of settler colonialism in which a stronger, more numerous, and/or more technically advanced set of newcomers arrive, intending to be permanent settlers who displace and replace indigenous inhabitants. This interpretive framework has emerged within the disciplines of history and anthropology, offering a way to link the trajectory of English-speaking North 
America with the histories of other British-origin settler colonies. It can be applied with variations to Chile, Argentina, and Brazil as well as the United States and the so-called white dominions. In settler societies, colonists view Native peoples as obstacles to be contained or eliminated, rather than as potential workers or clients. The goal is replacement rather than accommodation. As theorist Patrick Wolfe writes, "settler colonialism destroys to replace" and "settler colonizers come to stay: invasion is a structure, not an event." The central action is to claim territory by displacing previous residents. One of the tools of settler colonialism is to define those previous residents as a distinct, racialized "other." ${ }^{36}$

The settler colonialism narrative has two sides. Scholars can focus on the target peoples and their strategies of accommodation and resistance, or on the actions and ideologies of newcomer settlers. For the United States, the second approach revises the overarching and positive Turnerian frontier narrative with an alter native master narrative of colonialism and Native displacement. ${ }^{37}$ Substitute one pejorative for another — "redneck" for "redskin" - and the Rajneesh adventure reads quite clearly as settler colonialism. ${ }^{38}$

Many - certainly not all — Rajneeshees arrived with general disinterest or scorn for Oregon, a state that was still rooted in a rural resource economy. Impressions might have come from Ken Kesey's sprawling novel Sometimes a Great Notion (1964) or its 1970 movie version with Paul Newman and Henry Fonda as irascible lone-wolf loggers. Portland, according to Sports Illustrated in commenting on the Trail Blazers' 1977 NBA championship, was a blue collar town..$^{39}$ Chicago Tribune reporters called it a "timber town" in $1981 .{ }^{40}$ The trendy hipster city depicted in the television comedy Portlandia (begun in 2011 and continuing today) was a long stretch away. Meanwhile, the new city-dwellers arrived in a landscape they could easily dismiss (or enjoy) as a throwback to earlier generations.

A sense of cultural superiority exacerbated the social and political distance that Rajneeshees felt between themselves and rural Oregonians. They were, by very definition as sannyasins, enlightened. They had found beliefs and behaviors that were fulfilling their needs, and they did not suffer opposition gladly. The Bhagwan enjoyed cultural conflict as a pathway to new understanding, and the Pune ashram had developed extreme and undisciplined forms of encounter groups that left some people enlightened and others damaged. Rajneeshees therefore were accustomed to much more aggressive and abusive forms of personal interaction than were reticent rural Oregonians and polite Portlanders. Harassing behaviors, such as surrounding and crowding a visiting land-use attorney, preventing him from inspecting public documents, and yelling anti-Semitic remarks, were dismissed as "play" or as a form of evangelism designed to "wake people up." Outrageous actions 
and rhetoric were justified as necessary to shock people into a "new level of functioning." "41 As was repeatedly noted, some of the interactions were like encounter groups for which the target/victim had not volunteered. Only after the collapse did some sannyasins acknowledge that "I guess that's part of our arrogance ... that we believed in, or bought into, about being better than, the rest of Oregon or humanity or whatever." 42

At the same time that they patronized, disparaged, and bullied their "native" neighbors, Rajneeshees also feared them as savages. Newspaper coverage that emphasized negative interactions fueled those fears. When bumper stickers and t-shirts read "Better dead than red" and mock announcements of "Rajneesh hunting season" circulated, it was easy to believe the worst and accept the need for tight control of access, even though there was no violence at or near the city. Two bombs that exploded on the second and third floors of Hotel Rajneesh in Portland on July 29, 1983, injured only the bomber but confirmed those fears, leading to the construction of electric fencing, guard posts along the road from Antelope/Rajneesh, and elaborate vetting of visitors. In the winter of 1983-1984 they acquired automatic weapons and helicopter reconnaissance teams. Rajneesh spokespersons increasingly claimed that the city was facing a war of religious persecution, a characterization that residents found it easy to accept because there were examples of bigoted rhetoric that confirmed their disdain for Oregonians. ${ }^{43}$ After the breakup of the city, a number of residents noted their surprise that some Oregonians were actually tolerant or even friendly. ${ }^{44}$

The immediate neighbors of the Big Muddy Ranch were especially behind the times in the eyes of New Yorkers, San Franciscans, and Europeans. The local economy revolved around small-scale ranching without Texas glamour. Antelope was tiny and dilapidated, and its residents were old compared with the Rajneeshees..$^{45}$ In effect, the Bhagwan, Sheela, and community members defined southern Wasco County as terra nullius, a land lying waste and abandoned. Not only was it a physically neglected landscape that cried out for improvement, but it was also a land effectively unpopulated — or populated by people whose actions and inactions defined them as a vanishing race. Sheela put it quite bluntly. Writing to Gov. Victor Atiyeh, she disparaged "stagnant, dilapidated little towns like Antelope - places where indolent old people go to mark time until they die." ${ }^{46}$

Rajneesh assumptions about the need for a defensive perimeter and about the inevitable decline of Antelope justified its aggressive conquest. The first stage was the legal takeover. In the early months, Rajneeshees bought several Antelope properties for retail and office activities. When their presence continued to grow, the town tried to deny further permits for much larger operations, only to be overruled by Wasco County. Local residents 


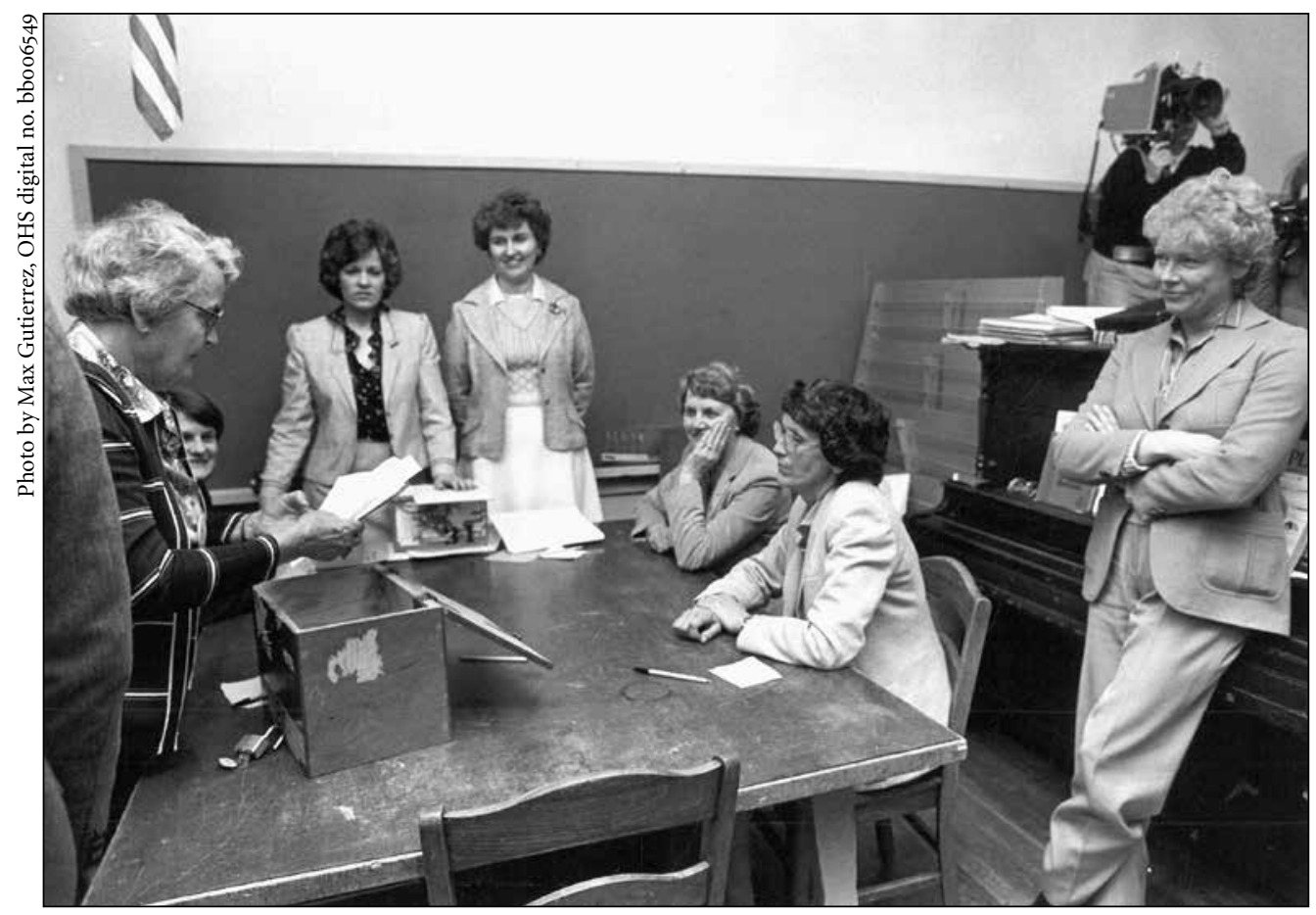

In 1982, then Secretary of State Norma Paulus (standing on the right), watches as Francis McKay removes ballots from a ballot box after an emergency election that failed to disincorporate the city of Antelope.

then moved to disincorporate the town, an action that Rajneeshees blocked by moving a large group from the ranch into town and taking advantage of Oregon's liberal voter-registration law. After defeating disincorporation 55 to 42 in April 1982, Rajneeshees won control of the Antelope City Council in November and took office in February 1983.

The second step was harassment of old-time residents. The council raised taxes, burdening retirees on fixed incomes. The town became Rajneesh, and the streets were given the names of Hindu holy men, turning elderly residents into strangers in their community. Law enforcement was contracted to the Peace Force, which patrolled with assault rifles. They directed searchlights through living room windows and shadowed residents on their daily rounds. The council located a landfill for Rajneeshpuram garbage next to the local church and dubbed it "Adolph Hitler Garbage Dump." ${ }^{47}$ Rajneeshees also took control of the local school district, bringing to the school children who had accompanied sannyasins to the ranch. 
Ranchers in the surrounding region had already arranged for their properties to be shifted from the Antelope school district to Jefferson County schools, in effect retreating from the Rajneeshees. Intimidation worked. A number of the older residents were driven from town, reflecting the argument of theorist Lorenzo Veracini that "settlers['] colonial projects are specifically interested in turning indigenous peoples into refugees." By renaming Antelope streets they delegitimized local claims to authenticity, since the locally preferred Anglo-American names themselves memorialized the process of white occupation of Indian land. $4^{8}$

After Antelope, Rajneeshees set their sights on further expanding their sphere of influence. In what would prove to be disastrous overreach, they tried to gain control of the three-member governing board of Wasco County in the fall 1984 election. The leadership vigorously encouraged non-resident sannyasins and sympathizers to move to the city for the fall and register to vote in Wasco County. When those numbers (about 1,500 people) were insufficient, the leadership implemented a Share-a-Home program that involved busing 3,500 people experiencing homelessness from around the country to register as Wasco County voters. Federal officials monitored the program because the city's increasing secrecy led them to worry that something like the mass suicide in Jonestown, Guyana, in 1978 might be in the works. Those bussed in were hard to fit into the Rajneeshpuram system, however, and the effort fell short of making Rajneeshees and their temporary guests the dominant voting bloc. On October 25, the commune announced that it was dropping its write-in campaign and then began to dump many of its temporary residents in surrounding towns such as Madras. ${ }^{49}$

Related to this campaign was a mass poisoning incident. In two outbreaks in September, 750 residents and tourists who ate at several salad bars in The Dalles became ill with salmonella poisoning. A year later, after Sheela's flight, investigators found cultivated strains of salmonella in the basement of her house. There is no doubt that Rajneesh agents poisoned the salad bars. Why? Was it "to have some fun," as one leader put it? More likely, the September incidents were test runs to see if a significant portion of voters in The Dalles could be disabled before the election. Smallpox blankets may be largely a myth about American dispossession of Native peoples, but unequal disease regimes were a deadly reality of which early leaders on both sides were quite aware. ${ }^{50}$ Salmonella poisoning was equally real.

\section{THE REGULATED WEST}

The narratives of the frontier utopia and the blossoming desert, and the alternative narrative of settler colonialism, are all stories about the white pioneering and homesteading eras of American history from settlement origins 
into the early twentieth century. They are about the power and opportunity to create something new in a controllable environment. Rajneesh leaders looked at Oregon and thought they saw the same unregulated landscape that had greeted Oregon Trail pioneers; more specifically, Sheela had not bothered to check about zoning restrictions before buying the ranch. ${ }^{51} \mathrm{In}$ a sense, the Rajneesh leaders and community members believed they were privileged to reenact nineteenth-century stories - as the winners. Indeed, some arrived with expectations that their new efforts would be recognized and honored in the same way that history books and western movies honored their putative predecessors.

In fact, twentieth-century counter narratives actually played out. Eastern Oregon may have looked empty to sannyasins, with few people and skimpy economic activity, but it was institutionally full, layered with regulations enforced by public bureaucracies. The history of the twentieth-century West is inextricably bound with the extension and articulation of state power through infrastructure investment, the defense establishment, immigration control, trade policy, education policy, welfare programs, and resource management agencies directed by men whom Richard White calls "captains of bureaucracy." ${ }^{2}$ There would have been few retirees to push out of Antelope without Social Security checks. There would have been no Rajneeshpuram without federal hydropower dams and the Bonneville Power Administration, not to mention federal air traffic controllers to help Bhagwan and sannyasins get to Oregon and state and federal highway funds to smooth the road to Madras for the Bhagwan's drives.

Rajneeshpuram collapsed in large part because its leaders ran up against regulatory systems - particularly relating to land use and to elections that limited their options. They might have modified their related goals of creating an intentional community for sannyasins and an expensive destination resort. Instead, they challenged the regulations with litigation, with efforts to wield political influence, and finally with illegal actions, failing in each effort. ${ }^{53}$

In the initial stages, Rajneeshees and public officials engaged in potentially fruitful dialogues. Many sannyasins had professional skills, and some had Oregon connections. Early on, Rajneeshees invited visitors, who were shown around by attractive women known as twinkies (a joke on the Hostess food product). A professionally staffed public relations department worked to smooth the waters, although Sheela's volatile personality and the escalation of the commune's public goals made their lives difficult. Rajneesh representatives met with the American Civil Liberties Union (ACLU) and with sympathetic politicians. They also held quiet conversations with the 


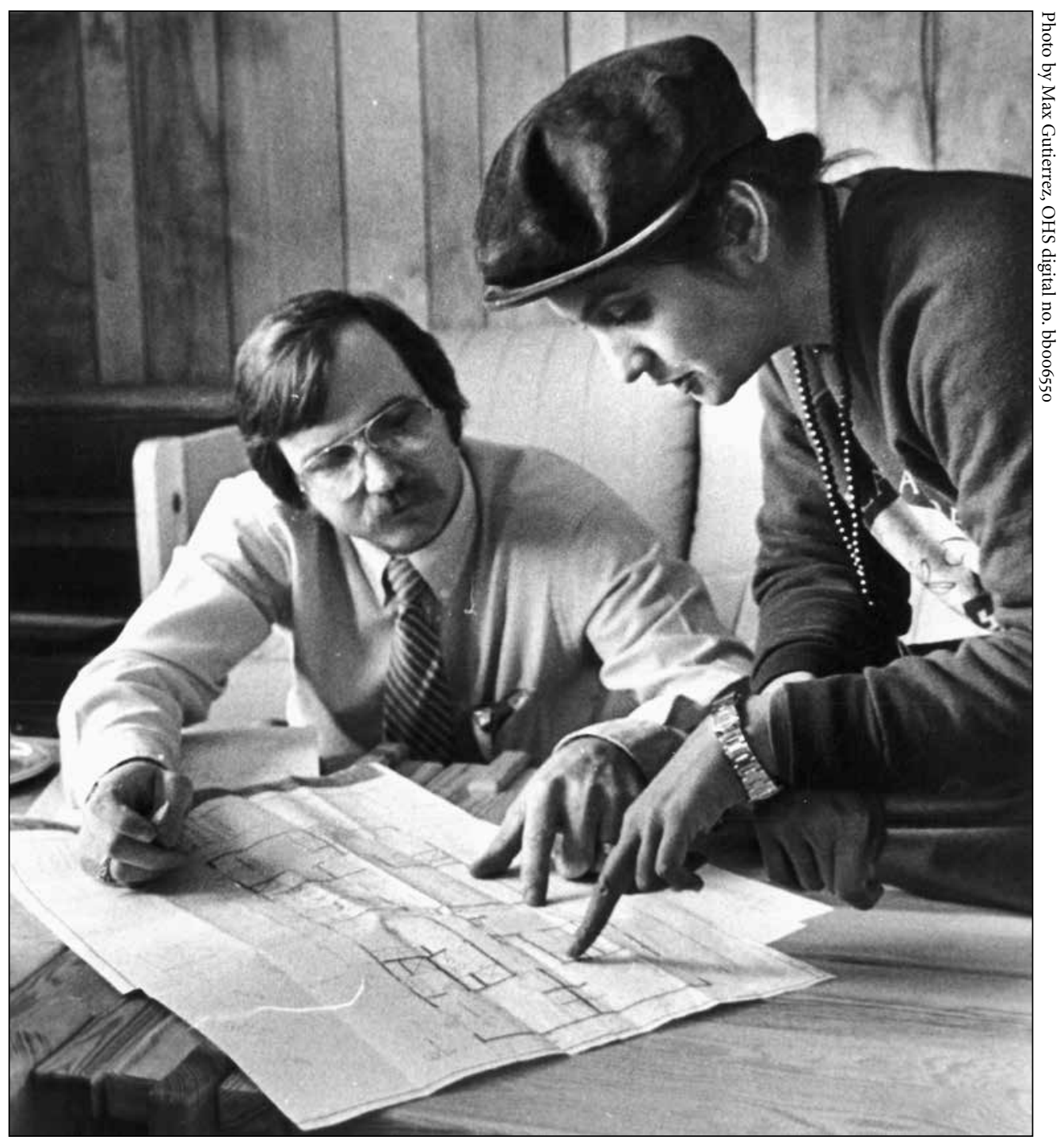

Ma Anand Sheela (right) and builder John Bauer go over plans for building Rajneeshpuram in March 1982.

Oregon attorney general's office. In turn, state law enforcement officials worked to assure that growing anti-Rajneeshee sentiment did not lead to potentially violent confrontations. They knew how easy it would be for angry Oregonians to take actions that would confirm the outside image of a state of backward bigots. ${ }^{54}$ 
Oregonians learned to dislike the Rajneeshee presence because of what seemed to be duplicity about their intentions and because of their aggressiveness - which Rajneeshees perceived as vigorous and preemptive self-defense. Preoccupied with the everyday routines of community building and their personal spiritual needs, large numbers of sannyasins paid little attention to the controversies that occupied their leaders. The farther away that observers or commentators were from eastern Oregon, the more favorable their view of the community and the less favorable their view of Oregonians. ${ }^{55}$ Locally, however, the Rajneeshee leadership found it increasingly difficult to control their image. Their attempts by 1984-1985 to close the city to any independent investigation made some observers fear that another Jonestown was in the making. ${ }^{56}$

Talk might have served Rajneeshpuram better had its leaders not been unrealistic about their potential for power and control, and had they been less impatient with the speed at which their desires might be accommodated. By 1983, Sheela was increasingly public in attacking opponents, calling State Representative Wayne Fawbush "Wayne Fascist" and telling Attorney General Dave Frohnmayer that he needed Rajneesh therapy for his obvious mental illness. With a number of skilled attorneys among the sannyasins, they found it easy to turn to litigation as a tool for both defense and intimidation. Lawsuits flew both ways - Rajneeshees suing officials for religious discrimination, Antelopers suing for defamation for being called racist, insane, or promiscuous. ${ }^{57}$

The legal challenge that most galled the Rajneeshees was a land-use challenge mounted by six nearby ranchers working with 1000 Friends of Oregon, a nonprofit organization established with the blessing of Gov. Tom McCall to defend the Oregon planning system. Federal agencies in the first half of the twentieth century had shifted from a resource-distribution regime to a resource- and land-management regime, epitomized by the creation and professionalization of the Forest Service and the transformation of the General Land Office and Grazing Service into the Bureau of Land Management. To again quote Richard White, "the central government ceased to be a nursemaid to the future states and a prodigal distributor of resources to the country's citizens and corporations. Washington instead became a manager of western land, resources, and, inevitably, people." 58 In Oregon, the enactment of statewide land-use regulations in 1973 and 1974 took the federal initiatives a big step further by bringing zoning and detailed land regulation to private as well as public land in every corner of rural Oregon.

In the preceding decade, the land-use lawyers with 1000 Friends had won a number of suits that blocked efforts to weaken or circumvent the 
state regulations. They were particularly adamant in fighting to maintain protections for agricultural lands. The incorporation of an entire new city on rural land was a red flag. The land itself was not of high value for agriculture, but 1000 Friends were lawyers, and lawyers think in terms of precedents. If Rajneeshpuram was legal, what would prevent a similar "city" from popping up in the middle of the immensely fertile Willamette Valley? So the organization challenged the basic legitimacy of the incorporation and won the first round, securing rulings in 1983 from the Land Use Board of Appeals (LUBA) and the Land Development and Conservation Commission (LCDC) that invalidated the city, initiating a four-year sequence of appeals and judicial actions..$^{59}$

This is the point at which Frohnmayer attacked the legitimacy of the city from a second direction. In October 1983, he issued an opinion that Rajneeshpuram, despite some of the trappings of a city, was in factual terms "the functional equivalent of a religious commune." ${ }^{\circ 0}$ As such, the constitutional separation of church and state rendered the settlement ineligible for state funding and participation in services intended for government entities (such as access to law enforcement data). The basis of the opinion was the monopoly of land ownership in the city by a nonprofit that was clearly an agent of the recently proclaimed church of Rajneeshism. The next month, the state filed a lawsuit seeking to dissolve the city on the constitutional basis. ${ }^{61}$

Had municipal status been denied but the community continued, it might have run up against Oregon limitations on the development of destination resorts on rural land. Rajneeshpuram was part of the tourism complex that has reshaped much of the American West in recent decades. A central narrative of the twentieth-century and twenty-first-century West is that of metropolitan reach. Cities not only trade with their hinterlands, but also claim rural resources for water supply, energy sources, waste disposal sites, prison locations, and recreation. Every western city is surrounded by a weekend-land that is heavily dependent on recreation and retirement dollars earned in the metropolis and spent in the mountains, along the coasts, by the lakes, among the wineries - in Hood River and Bend, Oregon, for example, in the general vicinity of the Big Muddy Ranch. Rajneeshpuram fell into a somewhat different category of "fly-in" resorts — such as Jackson, Wyoming, or Telluride, Colorado - that draw from the "global metropolis" of the mobile middle class. ${ }^{62}$

Survey evidence confirms that Rajneeshees were predominantly city people, and the community's economic future would have depended on a continual influx of new sannyasins and summer festival visitors, all bringing metropolitan money. ${ }^{63}$ At the same time, the Rajneeshees deliberately spread 


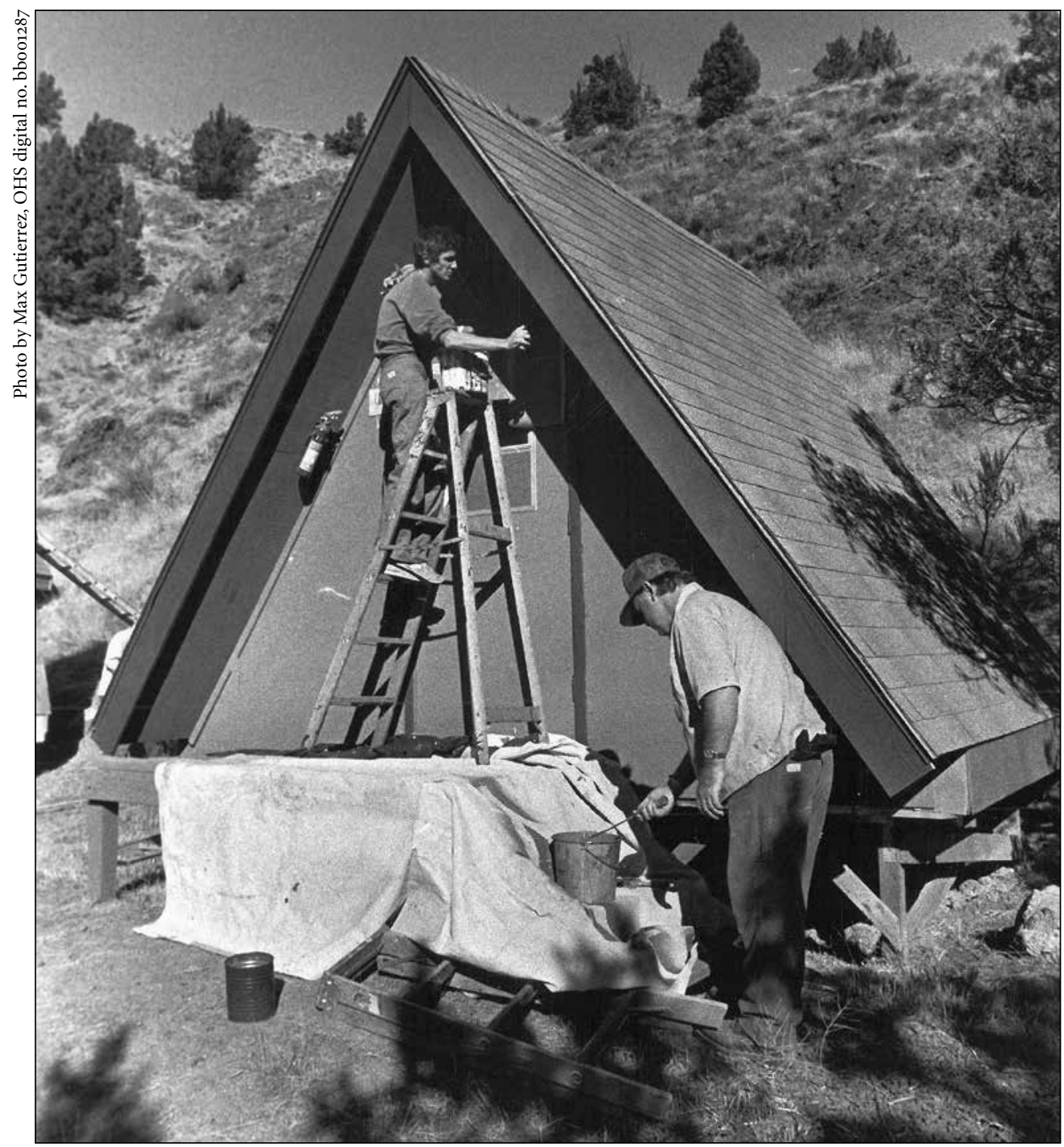

Two sannyasins paint and clean an A-frame structure built on old tent platforms for people experiencing homelessness. These structures were described by Rajneeshpuram as temporary housing, but state building officials disagreed because they were heated and wired for electricity.

money around central Oregon, buying food and construction supplies and ordering at least some of the Bhagwan's expensive automobiles through local dealers. Among other results, these purchases led to accusations of corruption against one Wasco County official. These actions can be seen as 
a small-scale step toward the "devil's bargain" described by Hal Rothman, in which resort communities gain investment and employment but lose local control of future development. ${ }^{64}$

A future as a permanent tourism community was never tested, because in 1984, the Rajneeshees ran up against Oregon Secretary of State Norma Paulus, the official charged with overseeing elections around the state. ${ }^{65}$ Oregon had lenient voter registration requirements, allowing registration up to twenty days before an election, but also requiring that voters show intent to stay in the state. Such judgment calls were usually handled at the county level and were seldom controversial, but the arrival of bus loads of people experiencing homelessness raised legitimate doubts. The threat of Mormon block voting had fueled hostility in Illinois in 1840 and again in Utah in the 1870 s and 1880 s, with efforts to disenfranchise polygamists and take the vote away from Mormon women. ${ }^{66}$

A century later, fears of a Rajneeshee election takeover triggered state action. When 3,00o voter registration cards flooded the inbox of the Wasco County clerk, Paulus decided that the state would assume direct responsibility for voter registration in Wasco County, and that all applications would be received in person in The Dalles rather than by mail. Not surprisingly, the first hearing on October 23 certified only 10 percent of 200 applicants, and Sheela soon dropped the Rajneesh write-in campaign. ${ }^{67}$ In effect, Paulus's action stymied the Rajneesh plans by tangling them in the web of election regulations.

Bureaucratic entanglement and public opposition increased after the election fiasco. Wasco County's planner had found his access blocked by carefully placed road equipment on previous tries to visit Rajneeshpuram, but in November, he managed to inspect the shelters that had been provided for the people experiencing homelesness. The state building code agency imposed a punitive fine of $\$ 1.5$ million when several hundred "winterized tents" proved to be permanent structures with electric wiring and piped gas that had been built without permits. The state Superintendent of Education forced curriculum changes by threatening to cut off aid to the Rajneeshpuram school because of its "religious" character. The Oregonian, Portland's major newspaper with a statewide circulation, published a twenty-part investigative exposé of the Rajneesh movement in July 1985, placing a powerful and relatively neutral shaper of opinion in the anti-Rajneesh camp. ${ }^{68}$ Perhaps because of the negative publicity, the stream of worldwide income and contributions that had built the city began to dry up; attendance at the 1985 summer festival just topped 3,000, down from 13,000 the year before. ${ }^{69}$

The pressures kicked the community from the older self-definition as a hopeful utopia to a new narrative of embattled outpost. As noted, levels 
of fear grew and defensive measures intensified. Purity of thought became increasingly important. Dissidents left or were isolated, and cliques battled for the ear of the Bhagwan (Sheela had the edge because of the wiretaps, bugs, and spy tunnels that she monitored). Although most residents, who overwhelmingly identified as politically and socially liberal, would have balked at the comparison, Rajneeshpuram took on similarities to the rightwing survivalist communities that had become a feature of the contemporary West: The government was out to get them, and the solutions were more isolation and more ammunition. ${ }^{70}$

This is the context in which the city fell apart from the top. Sheela and a small group of colleagues began to plot murder. They gave salmonellalaced water to visiting Wasco County officials, putting one in the hospital. They tried to burn the office of Wasco County planner Dan Durow. They schemed to kill Attorney General Dave Frohnmayer, U.S. Attorney Charles Turner, Oregonian reporter Les Zaitz, and probably several other individuals who had thwarted their plans. As the commune imploded, Sheela fled for Europe on September 13, 1985, ten city/church officials resigned on the fifteenth, and the Bhagwan denounced Sheela on the sixteenth, only to find himself indicted for immigration fraud. While his lawyer negotiated his voluntary surrender with the federal attorney, the Bhagwan boarded a private jet, only to be apprehended in Charlotte, North Carolina. What followed among the sannyasins was anger at Sheela and at Oregonians, denial that the city was doomed, resignation to the inevitable, and abandonment of the city - although for many, not abandonment of the Rajneesh affiliation, which has continued in small centers in the United States, Europe, and India.

\section{AFTERTHOUGHTS}

There are many frameworks for understanding and interpreting the dramatic story of Rajneeshpuram - as a new religious movement, an intentional community, a phenomenon of social control and cohesion, a set of individual transformations, a media event. This discussion has explored what we might learn from viewing it as an episode in the continuing history of the American West - as a celebratory narrative of resource development, a troubling story of colonial settlement and conquest, an example of metropolitan reach, and a manifestation of the expanding power of the state. 
It is instructive to complete an essay in western history by returning to the example of Utah. The Mormon community in the late 1850 os faced far more severe pressure than Rajneeshpuram ever felt; there is a big difference between an advancing federal army of three thousand and a state elections official. Mormon Utah survived because it was isolated and because Brigham Young was willing to compromise. The LDS leadership recognized that isolation was unsustainable and accepted the civil authority of the United States, giving up the governorship of Utah to a non-Mormon, in return for tacit religious tolerance that lasted for a generation. Rajneeshpuram, as I have tried to show, may have been physically distant, but it was politically, legally, and institutionally embedded. In contrast to Utah, Sheela did not want to acknowledge any limits that civil government might place on community goals. Neither the Bhagwan nor Sheela had Young's political skills and long-range vision. He could compromise to secure his religious community. They could not.

\section{NOTES}

1. Hugh B. Urban, “Zorba the Buddha: Capitalism, Charisma and the Cult of Bhagwan Shree Rajneesh," Religion 26:2 (1996): 161-82, offers a useful critical synthesis. Because the Bhagwan's writing and speeches run into the millions of words and wander over a vast range of topics, synthesis is a major undertaking.

2. A native of India, she was born Sheela Patel, married wealthy American Marc Silverman to become Sheela Silverman while studying at Montclair State University in New Jersey, and then took the name Ma Anand Sheela. After the death in India of her first husband, she married banker John Shelfer, who took the name Jayananda. She was almost universally known as Sheela.

3. The deal was agreed on June 13 and concluded on July 10, 1981, with ownership taken by the Chidvilas Rajneesh Meditation Center, a New Jersey nonprofit that also owned the Montclair mansion. The negotiator was Sheela's second husband, and the purchase required a loan from the Connecticut General Life Insurance Company, which was still owed $\$ 3.5$ million after the demise of Rajneeshpuram. See Lewis F. Carter, Charisma and Control in Rajneeshpuram (New York: Cambridge University Press, 1990) for the clearest description of the acquisition process.

4. Carter, Charisma and Control, 122. By 1982, The U.S. Immigration and Naturalization Service had initiated deportation procedures using the argument that he could not be in the United States as a religious worker when he had long claimed that he was not preaching a religion, but freedom from all 
religion. At that point, he proclaimed that Rajneeshism was indeed a religion with a set of rituals.

5. Marion Goldman, "Cultural Capital, Social Networks, and Collective Violence at Rajneeshpuram," in Violence and New Religious Movements, ed. James R. Lewis (New York: Oxford University Press, 2011), 309.

6. Frances FitzGerald, Cities on a Hill: A Journey through Contemporary American Cultures (New York: Simon and Schuster, 1986).

7. City of Rajneeshpuram, Comprehensive Plan (1982). Oregon's statewide planning system has been extensively studied. Overviews include Carl Abbott, Deborah Howe, and Sy Adler, eds., Planning the Oregon Way: A Twenty Year Evaluation (Corvallis: Oregon State University Press, 1994); Arthur C. Nelson and Garrett Knaap, The Regulated Landscape: Lessons on State Land Use Planning from Oregon (Cambridge, Mass.: Lincoln Institute of Land Policy, 1992); Peter Walker and Patrick T. Hurley, Planning Paradise: Politics and Vision of Land Use in Oregon (Tucson: University of Arizona Press, 2011).

8. Kirk Braun, Rajneeshpuram: The Unwelcome Society (West Linn, Ore.: Scout Creek Press, 1984); Dell Murphy, The Rajneesh Story: The Bhagwan's Garden (West Linn, Ore.: Linwood Press, 1986).

9. Robert Anderson, Behind the Red Door: The Rajneesh Exposed (Portland, 1983); Hugh Milne, Bhagwan: The God that Failed (New York: St. Martin's Press, 1986); Kate Strelley, The Ultimate Game: The Rise and Fall of Bhagwan Shree Rajneesh (New York: Harper and Row, 1987). James Gordon, The Golden Guru (New York: Viking, 1987) is by a sympathetic participant observer who followed the movement both in India and the United States and sadly watched it implode. 10. Win McCormack, The Rajneesh Chronicles: The True Story of the Cult that Sought to Kill Two Thirds of the Human Race (Portland, 1986).

11. FitzGerald, Cities on a Hill. Rajneeshpuram appeared thinly disguised as Ashram Arbat in John Updike's novel $S$ (New York: Knopf, 1988) and again in Michael Aaron
Rockland's novel A Bliss Case (Minneapolis: Coffee House Press, 1989).

12. Marion Goldman, Passionate Journeys: Why Successful Women Joined a Cult (Ann Arbor: University of Michigan Press, 1999); Carter, Charisma and Control. FitzGerald in Cities on a Hill also focused her analysis on the motivations behind the increasingly erratic behavior of the Rajneeshpuram residents.

13. Urban, "Zorba the Buddha"; Corinne G. Dempsey, Bringing the Sacred Down to Earth: Adventures in Comparative Religion (New York: Oxford University Press, 2012).

14. Arthur E. Bestor, Backwoods Utopias: The Sectarian and Owenite Phases of Communitarian Socialism in America, 1663-1829 (Philadelphia: University of Pennsylvania Press, 1950); Arthur E. Bestor, "Patent Office Models of the Good Society: Some Relations between Social Reform and Westward Expansion," American Historical Review, 53 (April 1953): 505-26.

15. Philip Porter and Fred Lukerman, "The Geography of Utopia," in David Lowenthal and Martyn Bowden, ed., Geographies of the Mind (New York: Oxford University Press, 1976); Robert V. Hine, California's Utopian Communities (San Marino, Cal.: The Huntington Library, 1953); Charles LeWarne Utopias on Puget Sound, 1855-1915 (Seattle: University of Washington Press, 1975); James Kopp, Eden within Eden: Oregon's Utopian Heritage (Corvallis: Oregon State University Press, 2009).

16. James Vance, "California and the Search for the Ideal," Annals of the Association of American Geographers 62:2 (1972): 185-210; Hugh Gardner, The Children of Prosperity: Thirteen Modern American Communes (New York, St. Martin's Press, 1978); Richard Fairfield, Communes, USA (Baltimore: Penguin, 1972); Iain Boal, Jenferie Stone, Michael Watts, and Cal Winslow, eds., West of Eden: Communes and Utopia in Northern California (Oakland, Cal.: PM Press, 2012).

17. Kenneth Lockridge, A New England Town: The First Hundred Years (New York: Norton, 1970). There is no way to know what the Rajneesh leadership read, but this book 
is likely to have been on college reading lists for many younger sannyasins.

18. Goldman, Passionate Journeys, 26.

19. Lowry Nelson, The Mormon Village: A Pattern and Technique of Land Settlement (Salt Lake City: University of Utah Press 1952), 48; Marvin S. Hill, Quest for Refuge: The Mormon Flight from American Pluralism (Salt Lake City: Signature Books, 1989).

20. Marion Goldman has probed the motivations of individuals in Passionate Journeys: Why Successful Women Joined a Cult. In the manner of Robert Bellah in Habits of the Heart: Individualism and Commitment in American Life (Berkeley: University of California Press, 1985), she used in-depth interviews to construct composite characters whose stories typify the ways in which the community attracted and affected well-educated, middle-class women, largely in positive ways even after the community's collapse.

21. Lawrence Foster, Women, Family, and Utopia: Communal Experiments of the Shakers, the Oneida Community, and the Mormons (Syracuse, NY: Syracuse University Press 1991), 207.

22. Braun, Rajneeshpuram, 28; Frances FitzGerald, "A Reporter at Large: Rajneeshpuram-1," The New Yorker, September 22, 1986, p. 279.

23. Carter, Charisma and Control, 133-35; James Long and Leslie Zaitz, "Network of Corporations Fueled Reign of Rajneesh," Oregonian, November 24, 1985.

24. Eugene Campbell, Establishing Zion: The Mormon Church in the American West, 1847-1869 (Salt Lake City, Utah: Signature Books, 1988), 6.

25. Donald W. Meinig, The Shaping of America: A Geographical Perspective on 500 Years of History, vol. 3: Transcontinental America, 1850-1915 (New Haven, Conn.: Yale University Press, 1998), 90-99.

26. David Bigler and Will Bagley, The Mormon Rebellion: America's First Civil War, 1857-1858 (Norman: University of Oklahoma Press, 2012); Campbell, Establishing Zion, 57-92. Young recalled these outlying settlers in 1857 to strengthen Utah in the pending war with the United States.
27. Sixty officers per one thousand residents is more than ten times the ratio found in heavily policed cities such as New York, Philadelphia, Baltimore, and St. Louis, and more than twenty times the Portland ratio. See http://www.city-data.com/top2/c423. html (accessed September 23, 2015).

28. Leonard J. Arrington, Great Basin Kingdom: An Economic History of the LatterDay Saints, 1830-1900 (Cambridge, Mass.: Harvard University Press, 1958); John W. Reps, Cities of the American West: A History of Frontier Planning (Princeton, NJ: Princeton University Press, 1979), 312-43; Nelson, Mormon Village; Campbell, Establishing Zion.

29. Carl Abbott, How Cities Won the West: Four Centuries of Urban Change in Western North America (Albuquerque: University of New Mexico Press, 2008), 89-99.

30. The details and tone of this paragraph come from Judith Thompson and Paul Heelas, The Way of the Heart: The Rajneesh Movement (San Bernardino, Cal.: The Borgo Press, 1988), 28-29, a sympathetic account by two British religion scholars that tends to channel the official Rajneeshee positions.

31. William E. Smythe, The Conquest of Arid America (New York: Macmillan, 1900); Ian Tyrrell, True Gardens of the Gods: California-Australia Environmental Reform, 1860-1930 (Berkeley: University of California Press, 1995); William Rowley, Reclaiming the American West (Bloomington: Indiana University Press, 1996).

32. Marion Goldman, personal communication, June 15, 2015.

33. Carl A. Latkin, Richard A. Hagan, Richard A. Littman, and Norman D. Sundberg. "Who Lives in Utopia? A Brief Report on the Rajneeshpuram Research Project," Sociological Analysis, 48:1 (Spring, 1987): 73-81; Goldman, Passionate Journeys, 14.

34. S. Ilan Troen, Imagining Zion: Dreams, Designs, and Realities in a Century of Jewish Settlement (New Haven, Conn.: Yale University Press, 2003), 3-81, quote p. 59. 35. Uri Herscher, Jewish Agricultural Utopias in America, 1880-1910 (Detroit, Mich.: Wayne State University Press, 1981); Taylor Spence, "Jeffersonian Jews: The Jewish Agrar- 
ian Diaspora and the Assimilative Power of the Western Land, 1882-1930," Western Historical Quarterly, 41:3 (Autumn 2010): 327-51; Pearl Bartelt, "American Jewish Agricultural Colonies," in Donald Pitzer, ed., America's Communal Utopias (Chapel Hill: University of North Carolina Press, 1997), 352-74; Robert Alan Goldberg, Back to the Soil: The Jewish Farmers of Clarion, Utah, and Their World (Salt Lake City: University of Utah Press, 1986) notes the initial sympathy of local Mormons for the Clarion colony, because of scriptural connections made between Jews and Latter-Day Saints and because of a shared history of persecution.

36. Quotes from Patrick Wolfe, "Settler Colonialism and the Elimination of the Native," Journal of Genocide Research, 8:4 (December 2008):388. See also Patrick Wolfe, Settler Colonialism and the Transformation of Anthropology (London: Cassell, 1999) and http://settlercolonialstudies.org (accessed September 23, 2015).

37. Walter L. Hixson, American Settler Colonialism: A History (New York: Palgrave Macmillan 2013) applies the model to the spatial and diplomatic expansion of the United States. James Belich, Replenishing the Earth: The Settler Revolution and the Rise of the Anglo World, 1783-1939 (New York: Oxford University Press, 2001) applies it more broadly to the creation of a global set of English-speaking nations.

38. Religion scholar Corinne Dempsey in Bringing the Sacred Down to Earth has developed this line of analysis, emphasizing symbolic displacement and noting the Rajneeshee use of "redneck" (p. 82).

39. "Blazers All the Way," Sports Illustrated, June 13, 1977.

40. Paul Gapp, John McCarron, and Stanley Ziemba, The American City (Chicago: Chicago Tribune, 1981), 51.

41. Carter, Charisma and Control, 198.

42. Carl Latkin, "Seeing Red: A SocialPsychological Analysis of the Rajneeshpuram Conflict," Sociological Analysis, 53:3 (Autumn 1992): 267.

43. Carter, Charisma and Control, 197-98. 44. Latkin, "Seeing Red," 267.
45. Not far away was Shaniko, a very minor tourist destination as a ghost town dating from the early twentieth-century sheep-herding boom. It would have been easy for someone familiar with eastern Oregon to put Antelope in the same category.

46. Quoted in Garrett Epps, To an Unknown God: Religious Freedom on Trial (New York: St. Martin's Press, 2001), 77.

47. Dempsey, Bringing the Sacred Down to Earth, 84; Urban, "Zorba the Buddha," 167.

48. Lorenzo Veracini, Settler Colonialism: A Theoretical Overview (New York: Palgrave Macmillan, 2010), 35; Dempsey, Bringing the Sacred Down to Earth, 84, 100-101.

49. They would have had greater success with their electoral ambitions if Sheela had chosen a different location in Oregon. Wasco County had a 1980 population of 21,732 and Jefferson County 11,619. Just to the east across the John Day River, however, Gilliam and Sherman counties had just over 2,00o residents each and Wheeler County only 1,396. Carter, Charisma and Control, 222.

50. Elizabeth Fenn, "Biological Warfare in Eighteenth Century North America: Beyond Jeffery Amherst," Journal of American History," 86:4 (March 2000): 1152-80.

51. Epps, To an Unknown God, 70.

52. Richard White, "It's Your Misfortune and None of My Own": A New History of the American West (Norman: University of Oklahoma Press, 1991), 399; Carl Abbott, "The Federal Presence," in Clyde A. Milner, II, Carol A. O'Connor, and Martha A. Sandweiss, eds., The Oxford History of the American West (New York: Oxford University Press, 1994), 469-500; Karen Merrill, Public Lands and Political Meaning: Ranchers, the Federal Government, and the Property Between Them (Berkeley: University of California Press, 2002); James Silken, The Nation's Largest Landlord: The Bureau of Land Management in the American West (Lawrence: University Press of Kansas, 2009).

53. This section overlaps my article "Utopia and Bureaucracy: The Fall of Rajneeshpuram, Oregon," Pacific Historical Review, 59:1 (February 1990): 77-103, supplemented by the subsequent work of 
a number of scholars. Rather than using a western history framework, that article drew on political theory to understand the Rajneeshpuram experience as the contrast between a broker state in which factions bargain to resolve conflicts (expected by Rajneeshees) and a regulatory state (as encountered in Oregon).

54. Attorney General Dave Frohnmayer later commented that "part of our job was to keep the peace with people who agreed with the legal position we took but were impatient and even furious with the slow pace of the courts" and that his office attempted to reassure Rajneesh officials (oral history transcript quote in Goldman, "Cultural Capital," 318-20). Carter, Charisma and Control, 222.

55. B. Van Driel and J. van Belzen, "The Downfall of Rajneeshpuram in the Print Media: A Cross-national Study," Journal for the Scientific Study of Religion, 29 (1990): 76-90 compares coverage in the United States, Germany, and the Netherlands.

56. Carter, Charisma and Control, 202, 214-15.

57. Epps, To an Unknown God, 81; Latkin, "Seeing Red," 26

58. White, "It's Your Misfortune and None of My Own," 399.

59. In detail, LCDC had originally accepted the validity of Rajneeshpuram's comprehensive plan. In July 1983, however, LCDC adopted a retroactive administrative rule on incorporation of new cities that invalidated Rajneeshpuram. In September, LUBA ruled that the incorporation had violated the administrative rule and two state land-use goals. The Wasco County circuit court then enjoined further development under authority of the City of Rajneeshpuram. Development continued, of course, while appeals ping-ponged around the legal system.

6o. Epps, To an Unknown God, 86.

61. James T. Richardson, "State and Federal Cooperation in Regulating New Religions: Oregon Versus the Bhagwan Rajneesh," in James T. Richardson, ed., Regulating Religion: Case Studies from Around the Globe
(New York: Kluwer Academic, 2004), 477-89. The two lawsuits had interesting outcomes. In December 1985, when the city was rapidly dissolving, the federal district court agreed with Frohnmayer's arguments and ordered Rajneeshpuram to cease exercising governmental powers. In 1997, Oregon courts held on narrow grounds that the city's incorporation had been acceptable under Oregon land use law. Although seemingly contradictory, both decisions were moot because the "city" was evaporating both as a settlement and as an organization.

62. Lincoln Bramwell, Wilderburbs: Communities on Nature's Edge (Seattle: University of Washington Press, 2014).

63. Latkin, et al., "Who Lives in Utopia?"

64. Hal Rothman, Devil's Bargains: Tourism in the Twentieth-Century American West (Lawrence: University Press of Kansas, 1998).

65. Secretary of State is a statewide elected office, often seen as a stepping stone toward a run for U.S. Senator or Governor. Because Oregon has no office of Lieutenant Governor, the Secretary of State succeeds as Governor in case of an incumbent's death or resignation.

66. David Bigler, Forgotten Kingdom: The Mormon Theocracy in the American West, 1847-1896 (Logan: Utah State University Press, 1998).

67. Abbott, "Utopia and Bureaucracy," 97.

68. Abbott, "Utopia and Bureaucracy," 98. The Oregonian series is archived at http:// www.oregonlive.com/rajneesh/index.ssf/ rajneesh_story_archive.html. A retrospective series of articles in April 2011 by Les Zaitz, the key Oregonian reporter on the story in the 1980 s, highlights the community's criminal activities and collapse (http: www.oregonlive. com/Rajneesh/).

69. Carter, Charisma and Control, 122.

70. Latkin, et al., "Who Lives in Utopia?"; James Aho, Politics of Righteousness: Idaho Christian Patriotism (Seattle: University of Washington Press, 1995); Eckard V. Toy, "Promised Land or Armageddon? History, Survivalists, and the Aryan Nations in the Pacific Northwest," Montana: The Magazine of Western History, 36:3 (September 1986): $80-82$. 